ENHANCEMENT OF STORAGE STABILITY OF WHEAT GERM OIL BY ENCAPSULATION

\author{
A THESIS SUBMITTED TO \\ THE GRADUATE SCHOOL OF NATURAL AND APPLIED SCIENCES \\ $\mathrm{OF}$ \\ MIDDLE EAST TECHNICAL UNIVERSITY
}

\begin{abstract}
BY
MELTEM KARADENIZZ

IN PARTIAL FULFILLMENT OF THE REQUIREMENTS

FOR

THE DEGREE OF MASTER OF SCIENCE

IN

FOOD ENGINEERING
\end{abstract}

DECEMBER 2015 
Approval of the thesis:

ENHANCEMENT OF STORAGE STABILITY OF WHEAT GERM OIL BY ENCAPSULATION

submitted by MELTEM KARADENIZ in partial fulfillment of the requirements for the degree of Master of Science in Food Engineering Department, Middle East Technical University by,

Prof. Dr. Gülbin Dural Ünver

Dean, Graduate School of Natural and Applied Sciences

Prof. Dr. Alev Bayındırlı

Head of Department, Food Engineering

Prof. Dr. Serpil Şahin

Supervisor, Food Engineering Dept., METU

Prof. Dr. Gülüm Şumnu

Co-supervisior, Food Engineering Dept., METU

\section{Examining Committee Members:}

Doç.Dr. İlkay Şensoy

Food Engineering Dept., METU

Prof. Dr. Serpil Şahin

Food Engineering Dept., METU

Prof. Dr. Servet Gülüm Şumnu

Food Engineering Dept., METU

Yrd.Doç.Dr. Mecit Halil Öztop

Food Engineering Dept., METU

Yrd.Doç.Dr. Elif Yolaçener

Food Engineering Dept., Hacettepe University

Date: 07.12.2015 
I hereby declare that all information in this document has been obtained and presented in accordance with academic rules and ethical conduct. I also declare that, as required by these rules and conduct, I have fully cited and referenced all material and results that are not original to this work.

Name, Last name: Meltem Karadeniz

Signature: 


\title{
ABSTRACT \\ ENHANCEMENT OF STORAGE STABILITY OF WHEAT GERM OIL BY ENCAPSULATION
}

\author{
Karadeniz, Meltem \\ M., Department of Food Engineering \\ Supervisor : Prof. Dr. Serpil Şahin \\ Co-Supervisor: Prof. Dr. Gülüm Şumnu
}

December 2015, 85 pages

Wheat germ oil is a rich source of omega 3 and omega 6-fatty acids, octacosanol and tocopherol which has vitamin E activity. Due to these properties it is very beneficial for health but it is prone to oxidation in free form. Encapsulation provides protection of food ingredients from environmental stresses and increases the stability and functionality of the ingredient, which makes it possible to be used in functional foods.

The main objective of this study was to encapsulate wheat germ oil and to investigate its physicochemical properties and stabilities during storage. In encapsulation, aqueous solutions of maltodextrin (MD), gum arabic (GA), whey protein concentrate (WPC), chitosan (CS) and sodium caseinate $(\mathrm{NaCa})$ at different concentrations were used as wall material. Core to coating ratio was constant as 1:8. The effects of different homogenization techniques (ultrasonication (US), high speed blending by silent crusher (SC) and microfluidization (MF)) on particle size distributions of emulsions and efficiency 
of microcapsules were investigated. The effect of different treatment passes in MF was also studied. In addition, the capsules prepared at the optimum conditions were studied for their storage stability by determining totox value and $\alpha$ tocopherol concentration during storage at $15^{\circ} \mathrm{C}$ and $45^{\circ} \mathrm{C}$ at $33.3 \% \mathrm{RH}$ and $31.10 \% \mathrm{RH}$, respectively.

$\mathrm{NaCa}$ was found to have better encapsulation properties than CS, WPC and GA in encapsulation of wheat germ oil. The SC and MF techniques were better in the formation of stable emulsions as compared to US. The change in treatment passes of MF did not have significant effect on encapsulation efficiencies; on the other hand, the increase in treatment passes decreased particle size of the emulsions. When storage temperature was $15^{\circ} \mathrm{C}$, even the non-encapsulated oil was stable to oxidation. Storage stability analyses showed that rate of oxidation of fresh oil was higher than that of encapsulated oil stored at $45^{\circ} \mathrm{C}$ and microcapsules could maintain their stability for 20 days.

Keywords: Microencapsulation, wheat germ oil, sodium caseinate, microfluidization, totox value 


\title{
RUŞEYM YAĞININ DEPOLAMA STABİLITESSININ KAPSÜLLENEREK ARTTIRILMASI
}

\author{
Karadeniz, Meltem \\ Yüksek Lisans, Gıda Mühendisliği Bölümü \\ Tez Yöneticisi : Prof. Dr. Serpil Şahin \\ Yardımcı Tez Yöneticisi : Prof. Dr. Gülüm Şumnu
}

Aralık 2015, 85 sayfa

Buğday ruşeym yağı, omega 3 ve omega 6 yağ asitleri, oktasanol ve $E$ vitamin aktivitesi gösteren tokoferol bileşenleri açısından zengindir. Bu bileşenleri ile sağlığa oldukça yararlıdır; fakat serbest halde oksidasyona eğimlidir. Kapsülleme gıda bileşenlerinin çevresel etmenlere karşı korunmasını sağlar. Gıdanın stabilitesini ve işlevselliğini arttırarak fonksiyonel gıdalarda kullanılabilmesini sağlar.

$\mathrm{Bu}$ çalışmanın amacı, buğday ruşeym yağının kapsüllenmesi ve kapsüllerin fizikokimyasal özellikleri ile depolama sırasındaki dayanıklılıklarının incelenmesidir. Kapsüllemede, kaplama malzemesi olarak farklı konsantrasyonlarda maltodekstrin (MD), arap zamkı (GA), peynir altı suyu protein konsantresi (WPC), kitosan (CS) ve sodyum kazeinat (NaCa) sulu çözeltileri kullanılmıştır.Yağ:kaplama malzemesi oranı 1:8 olarak sabitlenmiştir. Ultrasonikasyon (US), yüksek hızlı karıştırma (SC) ve mikroakışkanlaştırma (MF) 
homojenizasyon tekniklerinin kapsülleme verimliliği ve parçacık boyutu dağılımı üzerindeki etkisi incelenmiştir. Ayrıca, farklı sayıda mikroakışkanlaştırma işleminde döngü sayısının etkisi de çalışılmıştır. Buna ek olarak, optimum koşullarda hazırlanan kapsüllerin $15^{\circ} \mathrm{C}$ ve $45^{\circ} \mathrm{C}$ sıcaklıklarda göreceli olarak $33.3 \%$ ve \%31.1 bağıl nem koşullarında saklanmaları sırasında totox değeri ve $\alpha$ tokoferol konsantrasyonu tespit edilerek raf ömrü stabiliteleri çalışılmıştır.

$\mathrm{NaCa}$ kaplama malzemesinin, buğday rüşeyminin kapsüllenmesinde, CS, WPC ve GA'dan daha etkili olduğu görülmüştür. SC ve MF homojenizasyon tekniklerinin stabil emülsiyon oluşturmada US'den daha iyi olduğu görülmüştür. MF döngü sayısındaki artış, kapsülleme verimini etkilememiştir; fakat diğer yandan işlem sayısı arttıkça emülsiyon parçacık boyutu küçülmüştür. Depolama sıcaklığ $15^{\circ} \mathrm{C}$ olduğunda kapsüllenmeyen yağ bile oksidasyona dayanıklıdır. Raf ömrü dayanıklılık analizleri, $45^{\circ} \mathrm{C}$ 'de kapsüllenmemiş yağın oksidasyon hızının kapsüllenen yağdan daha yüksek olduğunu ve kapsüllerin dayanıklılığının 20 gün korunabildiğini göstermiştir.

Anahtar Kelimeler: Kapsülleme, buğday ruşeym yağı, sodyum kazeinat, mikroakışkanlaştırma, $\alpha$-tokoferol 
To my family... 


\section{ACKNOWLEDGEMENTS}

I would like to express my greatest gratitude to my supervisor Prof. Dr. Serpil Şahin and my co-supervisor Prof. Dr. Gülüm Şumnu for their support and guidance throughout my thesis study. I am indebted to both of them for their suggestions, comments and effort that help me to take this study one step further to complete.

I would like to thank to Asst. Prof. Dr. Mecit Halil Öztop and Asst. Prof. Dr. Umut Yücel for their assistance in using the nano-dispenser.

I am grateful to Hazal Turasan for introducing me with the laboratory, her guidance in the laboratory work and sharing her knowledge with me related to this study.

I am also very grateful to Betül Çilek for her assistance in my experiments, guidance in using the laboratory equipment and her special support in every time I need to be enlightened about this study.

I would like to thank to Ph. D. Zinet Aytanga Ökmen and Ph. D. Betül Söyler for their assistance in HPLC analysis for my study.

It is a pleasure for me to express my gratitude to my friends Elçin Bilgin, Ahmet Yıldız, Önay Burak Doğan and Sertan Cengiz for their company and fellowship that encouraged me during my thesis study.

Finally, I would like to express my gratitude to my family for providing me the opportunity of studying my graduate program. I am grateful for their endless support and understanding. 


\section{TABLE OF CONTENTS}

ABSTRACT

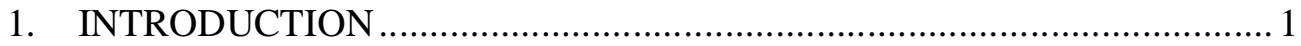

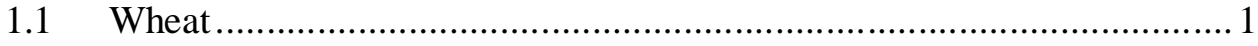

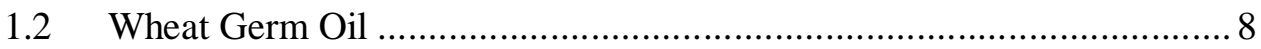

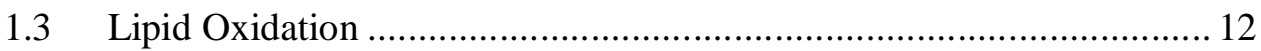

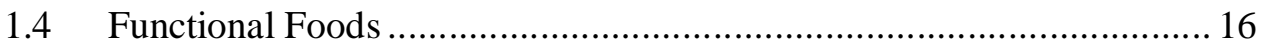

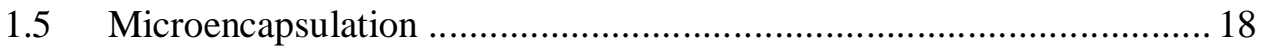

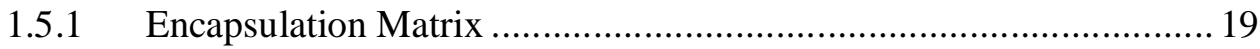

1.5.2 Emulsion Homogenization ................................................... 23

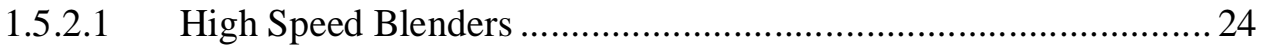

1.5.2.2 Ultrasonic Homogenizer ...................................................... 24

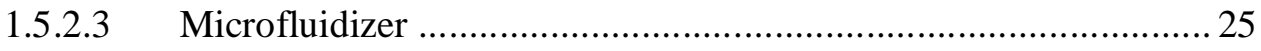

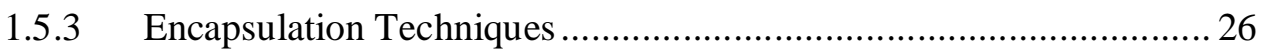

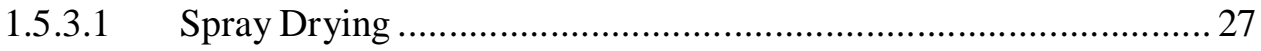

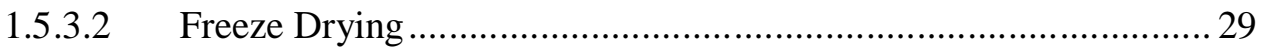

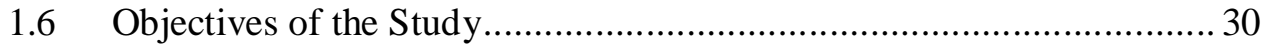

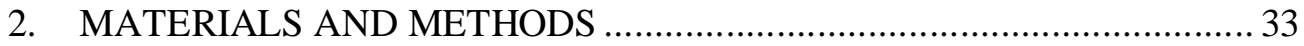




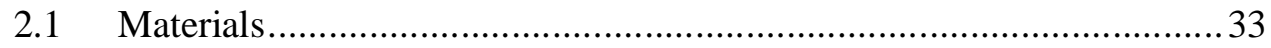

2.2 Microencapsulation of Wheat Germ Oil ............................................33

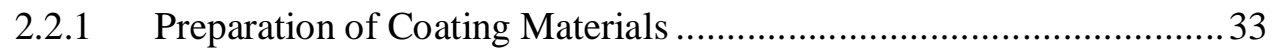

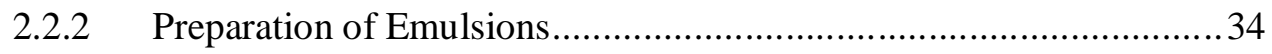

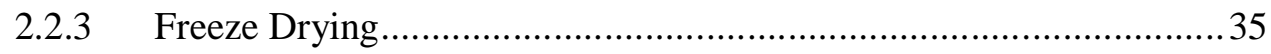

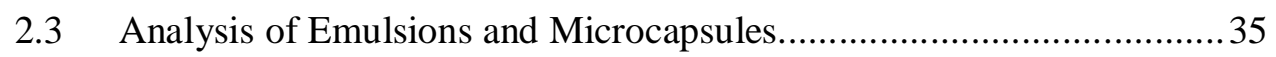

2.3.1 Efficiency Analyses of Microcapsules ....................................... 35

2.3.2 Particle Size Analyses of Emulsions ..............................................36

2.4 Storage Stability of Microcapsules ................................................ 37

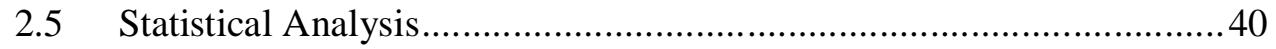

3. RESULTS AND DISCUSSION ..................................................... 41

3.1 Encapsulation Efficiency ......................................................... 41

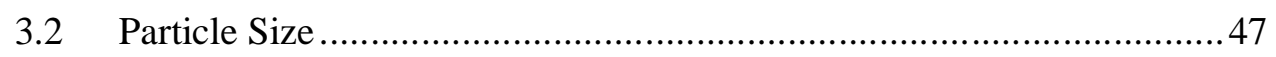

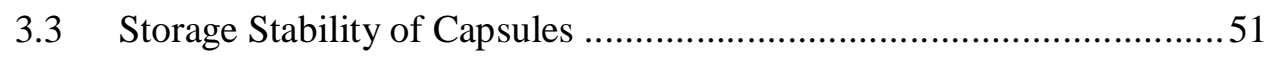

4. CONCLUSION AND RECOMMENDATIONS ....................................57

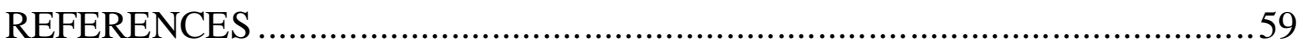

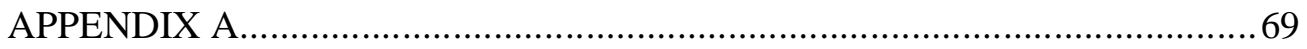

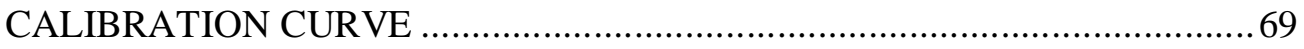

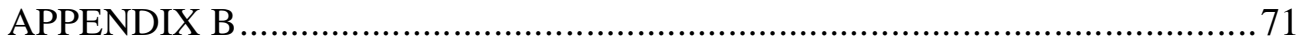

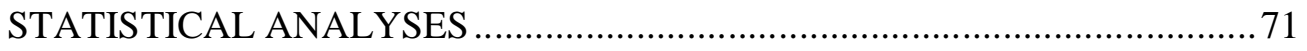




\section{LIST OF TABLES}

\section{TABLES}

Table 1.1 Human consumption of wheat based foods and of foods from all cereal sources in the year 2003 for the world. Source: FAOSTAT data, accessed in 2009 via the website (www.fao.org) (Wrigley \& Batey, 2010)................................. 2 Table 1.2 Weight, ash, protein, lipid and crude fiber contents of main anatomical parts of the wheat kernel and of flours of different milling extraction rates (Pomeranz, 1987) ................................................................................ 3

Table 1.3 Fatty acid composition of wheat and related products $(\mathrm{g} / 100 \mathrm{~g}$ food, edible portion) (Pomeranz, 1987).................................................................. 7

Table 1.4 Tocol derivatives in wheat (Khan \& Shewry, 2009) ......................... 11

Table 1.5 Coating materials in encapsulation (Garti \& McClements, 2012) ....... 21

Table 3.1 Effect of different freezing temperatures on surface oil content of

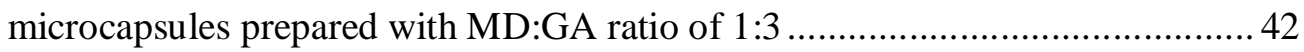

Table 3.2 Surface oil content (g oil/100 g capsule) of microcapsules prepared with different core to coating, different homogenization techniques and different

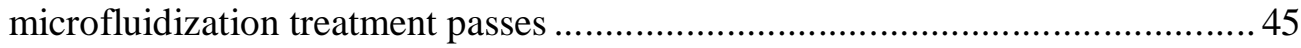

Table 3.3 The effect of different homogenization techniques on particle size results of emulsions prepared with $\mathrm{MD}: \mathrm{NaCa}$ ratio of $1: 3$............................. 48

Table 3.4 Particle size analyses of emulsions prepared with MD:NaCa ratio of 1:3 and homogenized with different microfluidization treatment passes ................. 50 


\section{LIST OF FIGURES}

\section{FIGURES}

Figure 1.1 The relationship among parts of the wheat spike or ear (Khan \&

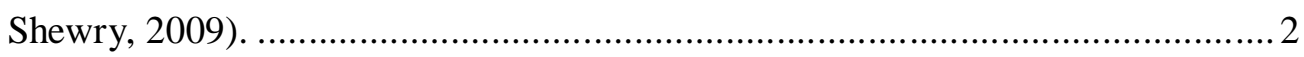

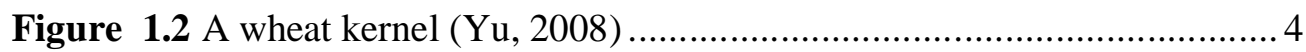

Figure 3.1 Encapsulation efficiencies of microcapsules prepared with MD:GA ratio of 1:3 and MD:WPC having different core to coating ratios. Different letters

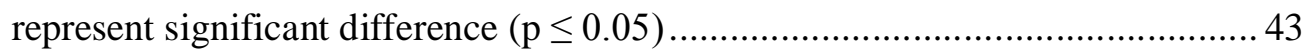

Figure 3.2 Encapsulation efficiencies of microcapsules prepared with constant ratio of $\mathrm{CS}$ and different core to coating ratios of MD:WPC. Different letters represent significant difference $(\mathrm{p} \leq 0.05)$.

Figure 3.3 Encapsulation efficiencies of microcapsules prepared with MD: $\mathrm{NaCa}$ ratio of 1:3 and homogenized with different techniques (ultrasonication (US), silent crusher (SC) and microfluidization (MF)). Different letters represent

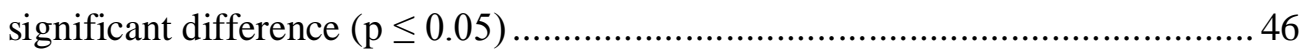

Figure 3.4 Encapsulation efficiencies of microcapsules prepared with $\mathrm{MD}: \mathrm{NaCa}$ ratio of 1:3 and homogenized under different microfluidization treatment passes. Different letters represent significant difference $(\mathrm{p} \leq 0.05)$.....

Figure 3.5 Particle size distributions of emulsions prepared with MD:NaCa ratio of 1:3 and homogenized with different techniques (ultrasonication (US)-dashed line, silent crusher (SC)-dotted line and microfluidization (MF)-solid line) ....... 49

Figure 3.6 Particle size distributions of emulsions prepared with MD:NaCa ratio of $1: 3$ and homogenized with different microfluidization treatment passes (1 pass: solid line, 2 pass: dashed line, 3 pass: dotted line) 51

Figure 3.7 Totox values of fresh oil and microcapsules prepared with MD:NaCa ratio of $1: 3$ and stored at $15^{\circ} \mathrm{C}$ for 40 days and $45^{\circ} \mathrm{C}$ for 28 days at $33 \% \mathrm{RH}$ ( $\bullet$ fresh oil at $15^{\circ} \mathrm{C}, \mathbf{m}$ : microcapsule at $15^{\circ} \mathrm{C}, \boldsymbol{\Delta}$ : fresh oil at $45^{\circ} \mathrm{C}, \bullet$ : microcapsule at $45^{\circ} \mathrm{C}$ ) 
Figure 3.8 $\alpha$-tocopherol concentration of fresh oil and microcapsules prepared with MD:NaCa ratio of $1: 3$ and stored at $15^{\circ} \mathrm{C}$ for 24 days and $45^{\circ} \mathrm{C}$ for 21 days at $33 \% \mathrm{RH}\left(\bullet\right.$ : fresh oil at $15^{\circ} \mathrm{C}, \mathbf{m}$ : microcapsule at $15^{\circ} \mathrm{C}, \boldsymbol{\Delta}$ : fresh oil at $45^{\circ} \mathrm{C}, \bullet$ :

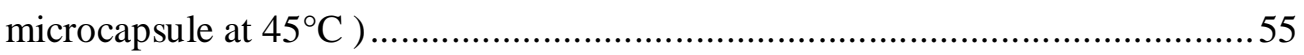




\section{CHAPTERS}

\section{INTRODUCTION}

\subsection{Wheat}

Cereal crops are the main supply for dietary food due to their nutritional composition and being a good source of energy. Besides human diet, through animal feeding and industrial applications cereal crops are major feeds providing protein and starch requirements for animal growth and industrial processes. In accordance to highly need of cereal crops, they are widely grown throughout the world. The World cereal production was about 2.3 billion tons in 2013 (Wrigley \& Batey, 2010; Dunford, 2012; FAO, 2014).

Wheat, which is one of the first and widely grown cereal crops, comprises twenty percent calories of human consumption. Nutritional characteristics, ease of growth and production of many different foods out of wheat make it the basic constitute of world's diet (Table 1.1) (Wrigley \& Batey, 2010; Pomeranz, 1987). Among all cereal crops, wheat is the one having the highest production and trade. According to FAO statistics, in 2013 the world wheat production was about 661 million tons as major cereal crop (FAO, 2014).

Wheat is cultivated on a broad land space over the world. It is adaptable to different climatic conditions from Arctic Circle to Equator and various types of land when the sufficient water is supplied. It has the highest growth yield in the regions where the temperature is moderate of about $15^{\circ} \mathrm{C}$ and the annual rain is high such as North America, Europe, Asia and North Africa (Pomeranz, 1987; Khan \& Shewry, 2009; Bushuk \& Rasper, 1994; Wrigley \& Batey, 2010). 


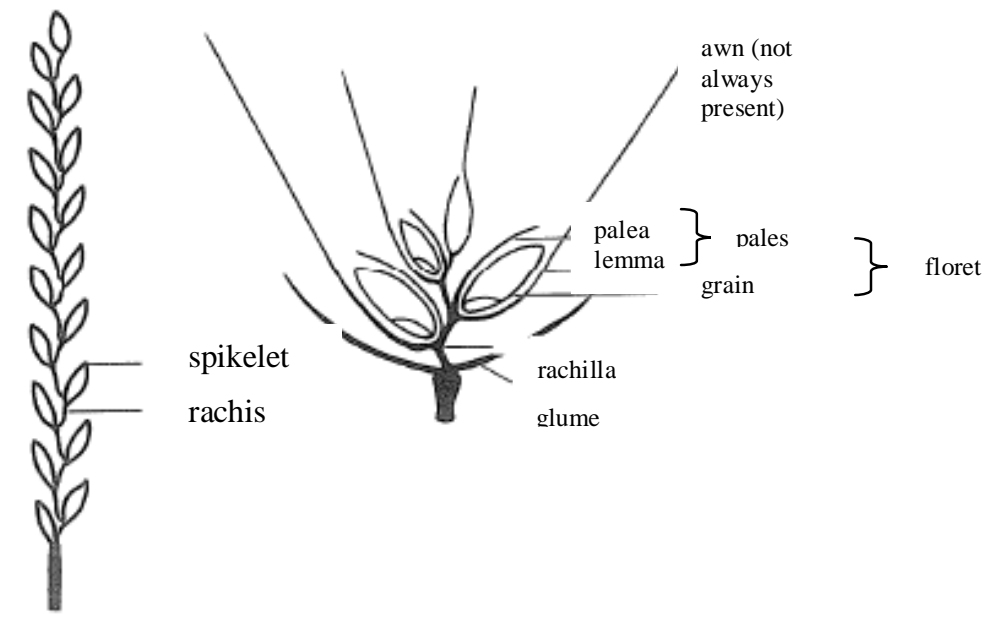

Figure 1.1 The relationship among parts of the wheat spike or ear (Khan \& Shewry, 2009).

Turkey is in the top ten among world wheat leading producers and annual wheat production was 20.5 million tons wheat produced annually in 2013 (FAO, 2013).

Table 1.1 Human consumption of wheat based foods and of foods from all cereal sources in the year 2003 for the world. Source: FAOSTAT data, accessed in 2009 via the website (www.fao.org; Wrigley \& Batey, 2010)

\begin{tabular}{cccc}
\hline & Units & From wheat & From all cereals \\
\hline Food & kg/person/year & 67 & 151 \\
Food & g/person/year & 184 & 414 \\
Protein & g/person/year & 15 & 31 \\
Fat & g/person/year & 31 & 5 \\
\hline
\end{tabular}


Wheat has botanical name Triticum under the grass family, Graminae called for cereals. Triticum aestivum and Triticum durum are the most widely grown among 5,000 species of Triticum genus. T. aestivum which is processed for the production of bread, cakes, pastries, biscuits, puddings, thickeners and noodles has about 90\% cultivation of total wheat growth (Bushuk \& Rasper, 1994; Wrigley \& Batey, 2010; Pomeranz, 1987). Wheat, the progeny of wild einkorn species, is further classified according to its agricultural and physical characteristics attributed to its chemical composition. Wheat is rich in chemical composition thereby one of the primary supplies for lipids, proteins, vitamins and minerals other than being a major contribution to daily calories (Bushuk \& Rasper, 1994; Pomeranz, 1987).

In Fig.1.1, the parts of wheat spike can be seen. Wheat grain (caryopsis) constitutes for almost half of total biomass in whole one seeded wheat crops. Its chemical composition differs in proportion along the layers of wheat kernel (Table.1.2). Structure of wheat kernel can be seen in Fig.1.2. (Pomeranz, 1987; $\mathrm{Yu}, 2008)$.

Table 1.2 Weight, ash, protein, lipid and crude fiber contents of main anatomical parts of the wheat kernel and of flours of different milling extraction rates (Pomeranz, 1987)

\section{Wheat kernel fractions}

\begin{tabular}{ccccc}
\hline Parameter & Pericarp & $\begin{array}{c}\text { Aleurone } \\
\text { layer }\end{array}$ & $\begin{array}{c}\text { Starchy } \\
\text { endosperm }\end{array}$ & Germ \\
Weight (\%) & 9 & 8 & 80 & 3 \\
Ash (\%) & 3 & 16 & 0.5 & 5 \\
Protein (\%) & 5 & 18 & 10 & 26 \\
Lipid (\%) & 1 & 9 & 1 & 10 \\
Crude fiber (\%) & 21 & 7 & $>0.5$ & 3 \\
\hline
\end{tabular}




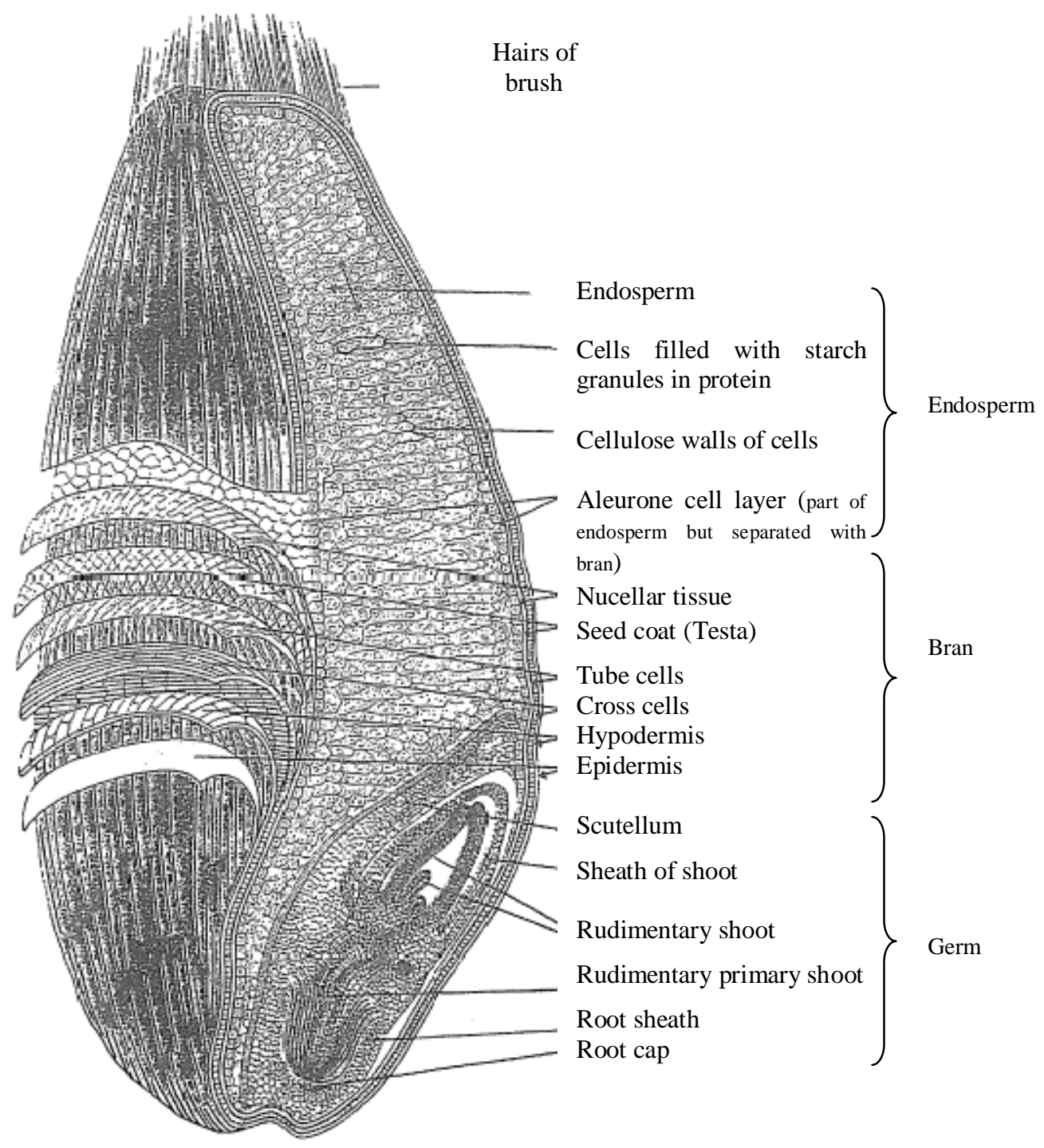

Figure 1.2 A wheat kernel (Yu, 2008) 
Endosperm is mainly formed of carbohydrates which are starch in majority, arabinose and xylose of free sugars, glucofructans, cellulose and hemicellulose. The considerable amount of wheat proteins is present in endosperm layer. These proteins are gliadin and glutenin proteins to a great extent (Dunford, 2012; Bushuk \& Rasper, 1994). The effect of wheat proteins on variation of product quality was studied by many researchers and their ability of creating viscoelastic structure which is the desired end product property was stated in several studies (Schofield, 2000). Magnesium, phosphorous and potassium are the minerals found in wheat grain. Thamine, riboflavin and niacin are present at high amounts in wheat grain and it is the richest source of vitamin E, namely tocopherols of tocols phytochemicals (Dunford, 2012; M. Eisenmenger \& Dunford, 2007). Besides tocols, there are other bioactive compounds as phenolics, alkylresorcinols, carotenoids and phytosterols highly found in bran and germ. The major phenolic acids in wheat are represented by ferulic acid and $p$-coumaric acid. Several researchers reported lutein, zeaxanthin, $\beta$-cryptoxanthin and $\beta$-carotene carotenoids present in different amounts for various types of wheat. The studies state that, depending on agricultural conditions, alkylresorcinols amount show variations for different wheat varieties. Broadly, the lipid content of wheat grain is 2.5-3.3\% and scattered along the layers of germ (30-36\%), endosperm (35-45\%) and the aleurone layer (25-29\%) in wheat kernel (Tokuşoğlu, 2011). Glycolipids at high amounts of digalactosyldiglycerides, monogalactosyldiglycerides and acyl monogalactosyldiglycerides, phospholipids which are mainly lysophosphatidylcholine, phosphatidylcholine, lysophosphatidylethanolamine, Nacylphosphatidyl ethanolamine and $\mathrm{N}$-acyl lysophosphatidyl ethanolamine and neutral lipids such as triglycerides mainly compose the wheat fatty acids (Dunford, 2012; Pomeranz, 1987; Tokuşoğlu, 2011). Palmitic (16:0) and stearic acid (18:0) of saturated fatty acids, oleic acid (18:1) of monounsaturated fatty acids and linoleic acid (18:2) of diunsaturated fatty acids include the majority of total fatty acids in wheat (Table 1.3) (Pomeranz, 1987).

Although the lipids are accepted as minor constituents besides starch and proteins in wheat, many studies show their functionality on chemical and physical 
properties resulting from the interactions with starch and proteins. Protein and lipid interactions contribute to gas retention and hence provide the stabilization of foam and emulsion. The interaction of wheat lipids with proteins was proven to have an influence on swelling and gelatinization (Tokuşoğlu, 2011; Schofield, 2000). The major contributors of wheat to human health are its phytochemicals located in bran and germ which are separated during wheat milling process due to lipid hydrolysis and oxidation concerns which lead chemical variations and eventually cause unfavorable results in nutrients and manufacture of products (Megahed, 2011).

About $11 \%$ of germ is oil and it contains tocopherols, polyunsaturated fatty acids, phytosterols and policosanol of bioactive compounds. Wheat germ oil is high in $\alpha$-tocopherol and it is well known for its vitamin E activity (Dunford, 2012). 


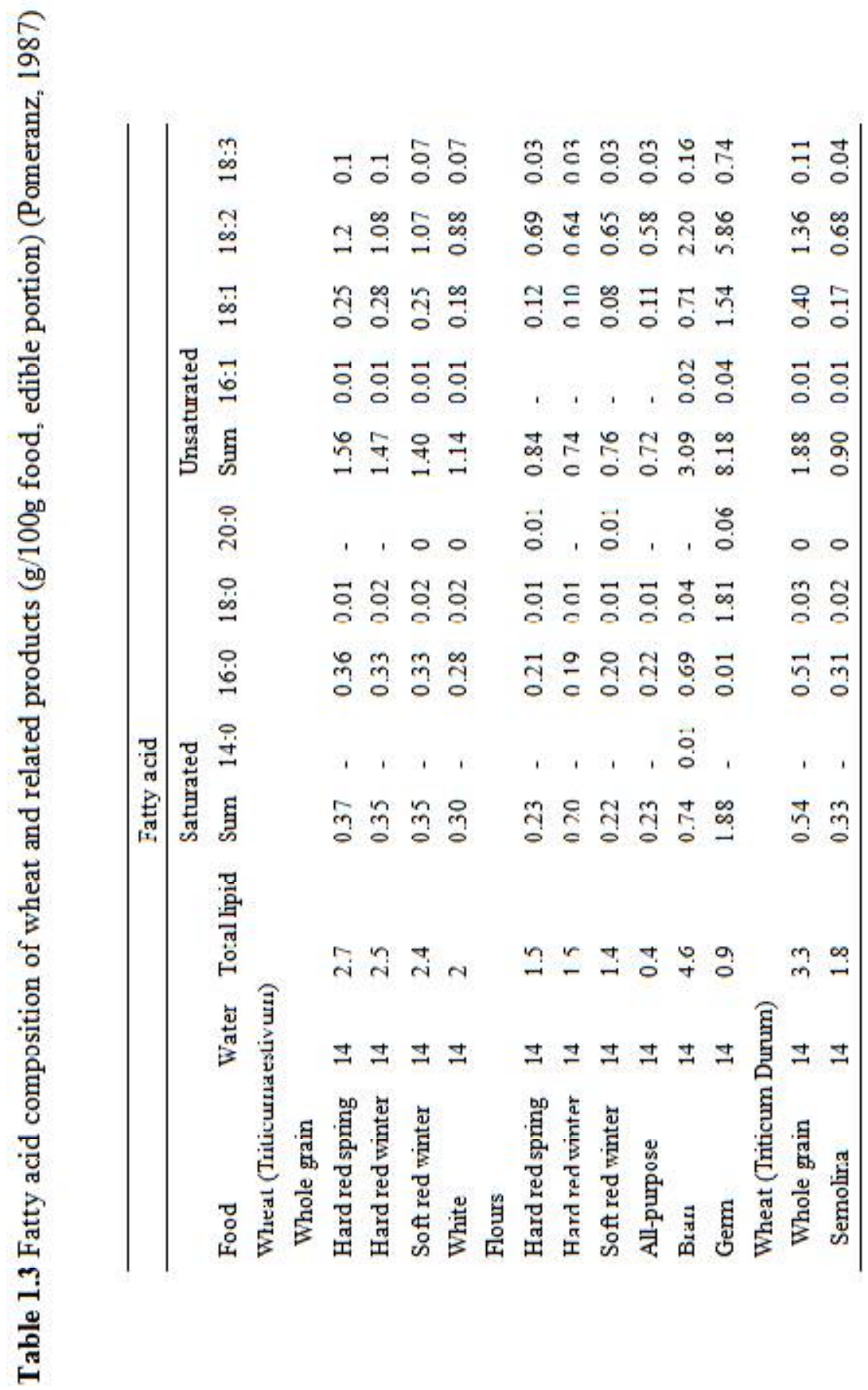




\subsection{Wheat Germ Oil}

Wheat germ is separated as by-product in flour milling process in order to eliminate the oxidation problems in flour during storage. The germ is the embryo and constitutes $2-3 \%$ of the wheat grain. The germ contains proteins, sugars, minerals and bioactive lipid classes which have beneficial influence on health due to its nutritional values (Megahed, 2011; Pomeranz, 1987; Tokuşoğlu, 2011).

Oil extraction process is dependent on raw material quality, chemical composition and production technique. Processing aims to produce high valued oil by discarding unwanted materials and obtain high extraction efficiencies. Solvent extraction, mechanical oil expression, aqueous extraction, enzyme and surfactant aided oil extraction and supercritical fluid technology are the techniques used for oil extraction from seeds (Dunford, 2012). Oil extraction from wheat germ has been recently worked by supercritical fluid technology. Although the yield was higher when hexane was used for wheat germ oil extraction than supercritical $\mathrm{CO}_{2}$, the higher amounts of bioactive compounds were obtained in supercritical $\mathrm{CO}_{2}$ than hexane extraction. The concentration of tocols increased, when the pressures were lowered in supercritical $\mathrm{CO}_{2}$ extraction, yet the extraction yield was lowered likewise (Tokuşoğlu, 2011).

Wheat germ oil has high amounts of $\alpha$-tocopherol, phytosterols, polycosanols, thiamin, riboflavin and niacin. It is known as $\alpha$-tocopherol source having the richest amount (Eisenmenger \& Dunford, 2007). Nonpolar lipids are present approximately $80 \%$ and polar lipids are present almost $18 \%$ of the germ lipids differing from the endosperm lipids which have higher amounts of polar lipids. Phosphatidylcholine, lysophosphatidylethanolamine, phosphatidylethanolamine and phosphatidylserine are the phospholipids present in wheat germ oil. $\beta$ sitosterol and campesterol are the main phytosterols at amounts of 63 and 27\% respectively. Fatty acid constitutes of wheat germ oil are $17 \%$ of palmitic acid, $1 \%$ of stearic acid, $17 \%$ of oleic acid, $59 \%$ of linoleic acid and $6 \%$ of $\alpha$-linoleic acid. 1,3-dipalmitoyl-2-linoleoyl-racglycerol (PLP), 1-palmitoyl-2,3-dioleoyl-rac- 
glycerol (POO), 1-palmitoyl-2-linoleoyl-3-oleoyl-glycerol (PLO), triolein (OOO), 1,2-dilinoleoyl-3-palmitoyl-rac-glycerol (PLL), linolenoyl-linoleoyl-palmitoylglycerol (PLLn), 1,2-dioleoyl-3-linoleoyl-rac-glycerol (OOL), 1,2-dilinoleoyl-3oleoyl-rac-glycerol (LLO), trilinolein (LLL) and linolenoyl-dilinoleoyl-glycerol (LLLn) are the main triacylglycerol species of wheat germ oil. Free fatty acid content of wheat germ oil varies between 5 to $25 \%$ depending on different wheat cultivars, handling, extraction and refining conditions (Tokuşoğlu, 2011; Özcan et al., 2013; Tokuşoğlu, 2011; Length, 2006; Koeber et al., 2003; Ayorinde, Eribo, Balan, Johnson, \& Wan, 1999; Huang, Ju, \& Huang, 1997).

The health promoting effect of wheat germ oil was cited by Wang \& Johnson (2001) as helping to reduce the plasma and liver cholesterol levels in animals, to enhance physical strength and to retard aging. The rich amount of tocopherols, linoleic acid and policosanol were indicated as the factors for the health benefits of wheat germ oil (Tokuşoğlu, 2011; Dunford, 2012). Health benefit of policosanol has been reported in many studies and its positive effects on lowering lipid levels have been stated broadly. Policosanol prevents the synthesis of

cholesterol and protects the lipoproteins as cited by Irmak, Dunford, \& Milligan (2006). Linoleic acid is very precious for human health for its being essential, since it cannot be synthesized from any source (Molero G mez \& Mart nez de la Ossa, 2000). Tocopherols are the natural antioxidants which protect the cell membrane from peroxidation of unsaturated fatty acids by acting as stabilizers. Tocopherols inhibit the oxidation of low-density lipoprotein (LDL) and hence prevent the vascular diseases (Megahad \& El Kinawy, 2007). Wheat germ oil is known as the richest source of $\alpha$-tocopherol. $\alpha$-tocopherol amount of wheat germ oil is the highest of all tocopherols (Table 1.4) (Khan \& Shewry, 2009). The amount of tocols is about $2500 \mathrm{mg} / \mathrm{kg}$ oil and $\alpha$-tocopherol constitute the $60 \%$ of this amount (Tokuşoğlu, 2011). Wheat germ oil is also used for skin care purposes for its chemical components. It is reported that the use of wheat germ oil enhances the blood circulation thereby helps renewing the skin cells (Kumar et al., 2011). 
Although $\alpha$-tocopherol shows the highest biological activity, its thermal stability is the lowest of other tocopherols (Bruscatto et al., 2009). A research studied on wheat germ oil to find out the effects of temperature of $27^{\circ} \mathrm{C}$ and $45^{\circ} \mathrm{C}$, and storage time of 35 days on tocopherol concentration revealed that the tocopherol concentration decreased when the temperature increased and tocopherol concentration decreased about $37 \%$ at $45^{\circ} \mathrm{C}$ and about $32 \%$ at $27^{\circ} \mathrm{C}$ in 35 days (Capitani, Mateo, \& Nolasco, 2011). $\delta$-tocopherol has higher thermal stability than $\alpha$-tocopherol, which was brought out by a study on rapeseed oil stored for 16 days at $40^{\circ} \mathrm{C}$ as cited by Bruscatto et al. (2009). Player, Kim, Lee, \& Min (2006) found out that the degradation of $\alpha$-tocopherol is faster than $\delta$-tocopherol and $\gamma$ tocopherol when the storage conditions are 24 days at $50^{\circ} \mathrm{C}$. In the same study, it was reported that the oxidation of unsaturated lipids affect the degradation of tocopherols (Player et al., 2006). 
Table 1.4 Tocol derivatives in wheat (Khan \&Shewry, 2009)

\begin{tabular}{|c|c|c|c|c|c|c|c|c|c|}
\hline & $\alpha-\mathrm{T}$ & $\alpha-T-3$ & $\beta-\mathrm{T}$ & $\beta-\mathrm{T}-3$ & $\gamma-\mathrm{T}$ & $\gamma$-T-3 & $\delta-\mathrm{T}$ & $\delta-\mathrm{T}-3$ & Total \\
\hline \multicolumn{10}{|l|}{ Wheat } \\
\hline Whole & $0.9-1.8$ & $0.3-0.7$ & - & $\begin{array}{l}2.5- \\
3.6\end{array}$ & - & - & - & - & $4.9-5.8$ \\
\hline \multirow[t]{3}{*}{ Germ } & 25.56 & $<0.2$ & 11.44 & $<0.2$ & - & - & - & - & - \\
\hline & $(98.0)$ & - & $(97.3)$ & & - & - & - & - & - \\
\hline & 22.1 & 0.3 & 8.6 & 1.0 & - & - & - & $<0.1$ & - \\
\hline \multirow{2}{*}{$\begin{array}{l}\text { Pericarp, } \\
\text { testa,and } \\
\text { aleurone }\end{array}$} & 0.05 & 1 & $<0.04$ & 6.86 & - & - & - & - & 7.91 \\
\hline & $(1.2)$ & $(81.2)$ & - & $(49.8)$ & - & - & - & - & - \\
\hline \multirow[t]{2}{*}{ Bran } & $1.6-3.3$ & 1.1 & $1.0-1.3$ & $\begin{array}{l}2.9- \\
5.4\end{array}$ & - & - & - & - & - \\
\hline & 1.6 & 1.5 & 0.8 & 5.6 & - & - & - & - & - \\
\hline \multirow[t]{2}{*}{ Endosperm } & 0.007 & 0.045 & 0.01 & 1.35 & - & - & - & - & 1.41 \\
\hline & $(0.08)$ & (18.8) & (2.7) & $(50.2)$ & - & - & - & - & - \\
\hline Patent flour & $\begin{array}{l}0.26- \\
0.34\end{array}$ & 0.14 & $\begin{array}{l}0.20- \\
0.22\end{array}$ & $\begin{array}{l}1.04- \\
2.18\end{array}$ & - & - & - & - & $1.5-2.8$ \\
\hline
\end{tabular}




\subsection{Lipid Oxidation}

Lipid oxidation is a significant reaction mechanism which leads to various consequences to be evaluated by multidiscipline. Along the production, handling, storage processes, food systems are subjected to oxidative stresses such as prooxidants, heat, lypoxygenases and light, shortening its shelf life. In relation to pathology, the physiological effects of oxidation occur as the biological destruction of membrane cells and organelles, vitamins and hormones which are essential for cell metabolism (Repetto, Semprine, \& Boveris, 2012; Wsowicz et al., 2004; Dubois, 1995; Report, 1992).

Oxidation is among the main contributors for the detrimental changes in foods containing considerable amounts of lipids such as products of meat and milk, oils, nuts and even vegetables which have low amounts of lipids. The effects of oxidation can be seen as the deterioration on especially the nutritional constituents of foods, flavor, aroma, color, leading to decrease in food quality. The volatile products such as carbonyl compounds and alcohols of secondary oxidation products cause the change in aroma. The flavor is modified by hydroxyl acids and the color gets dark as a result of condensation arisen from the interaction between proteins and oxidation products. The modifications on solubility, water holding and emulsification capacities resulted from these interactions bring about the texture and rheological variances. The reaction of hydroperoxide radicals with sulfur and amines which are functional groups of amino acids and the reaction between the thiols of cysteine and secondary oxidation products aldehydes and epoxides cause the break down or crosslink of proteins leading to nutritional changes in the product. Furthermore, peroxides and free radicals degrade the fat soluble vitamins A and E (Report, 1992; Dubois, 1995).

Lipid oxidation is a complex mechanism combining the sequence of enzymatic or non-enzymatic reactions. The process initiates with free radical formation and is followed with the attack by oxygen and change in double bond position in the lipid structure. It destroys the lipids in membrane and many oxidation products 
such as alcohols, ketones, alkanes, aldehydes and ethers are formed throughout the process (Repetto et al., 2012; Niki, Yoshida, Saito, \& Noguchi, 2005).

There are three mechanisms of lipid oxidation which are the free radical mechanism, photo-oxidation and process of lypoxygenase activity. A free radical mechanism, namely autoxidation, involves three stages of initiation, propagation and termination. In initiation step, free alkyl radical $(R \bullet)$ is formed after leaving of labile hydrogen atom from the fatty acid. The removal of hydrogen atom gets easier when the number of double bonds gets higher; therefore, polyunsaturated fatty acids are mostly exposed to oxidation. Then, hydroperoxides ( $\mathrm{ROOH})$ from the reaction of the fatty acids with radicals produced initially and peroxy radicals (ROO•) are formed in propagation step. Finally, non-radical products are formed between alkyl radicals and peroxy radicals in the termination step (Wsowicz et al., 2004; Halliwell, 1993; Dubois, 1995).

Initiation step:

$$
\mathrm{RH} \rightarrow \mathrm{R} \bullet
$$

Propagation step:

$$
\begin{aligned}
& \mathrm{R} \bullet+\mathrm{O}_{2} \rightarrow \mathrm{ROO} \bullet \\
& \mathrm{ROO} \bullet+\mathrm{RH} \rightarrow \mathrm{ROOH}+\mathrm{R} \bullet
\end{aligned}
$$

Termination step:

$$
\begin{aligned}
& \mathrm{R} \bullet+\mathrm{R} \bullet \rightarrow \mathrm{RR} \\
& \mathrm{R} \bullet+\mathrm{ROO} \bullet \rightarrow \mathrm{ROOR} \\
& \mathrm{ROO} \bullet+\mathrm{ROO} \bullet \rightarrow \mathrm{ROOR}+\mathrm{O}_{2} \text { (Wsowicz et al., 2004) }
\end{aligned}
$$

RR, ROOR, $\mathrm{O}_{2}$ are non-radical products (Wsowicz et al., 2004; Dubois, 1995).

The oxidation susceptibility of polyunsaturated fatty acids is higher than saturated fatty acids due to double bonds present in fatty acid chain. The weakness of carbon hydrogen bond in methylene group near the double bond makes labile 
hydrogen leave its site and be exposed to attack by oxygen. The factors affecting the product susceptibility to oxygen are the length of fatty acid chain, the degree of saturation and the distribution of fatty acids on the triglyceride (Repetto et al., 2012; Report, 1992).

Photo-oxidation mechanism is triggered by UV-light and a sensitizer. The interaction of unsaturated fatty acid and oxygen in this mechanism can happen in two different pathways. The first one is that the hydrogen is delivered between a polyunsaturated fatty acid and a triplet sensitizer. The second one is that the light transforms triplet oxygen $\left({ }^{3} \mathrm{O}_{2}\right)$ into singlet oxygen $\left({ }^{1} \mathrm{O}_{2}\right)$ reacting with the double bond of unsaturated fatty acids and forms an allylichydroperoxide (Wsowicz et al., 2004).

Another oxidation mechanism is catalyzed by lipoxyganase activity. Lipoxygenase is an enzyme containing iron atom in its active site and responsible for the formation of hydroperoxides from 1-4 pentadiene fatty acids. Hydrogen atom is abstracted from the fatty acid to release iron, leading to lipid peroxidation and the formation of conjugated diene system, eventually ending up with the production of peroxy radicals and hydroperoxides (Niki et al., 2005; Wsowicz et al., 2004).

Trace metals active in redox cycle reactions are prooxidants, catalysts of lipid oxidation involving in decomposing the hydroperoxides. Metal ions and hydroperoxides interact in redox reaction. Alkoxyl and proxyl radicals are generated, leading to autoxidation (Repetto et al., 2012; Wsowicz et al., 2004).

$\mathrm{Me}^{\mathrm{n}+}+\mathrm{ROOH} \rightarrow \mathrm{RO} \cdot+\mathrm{Me}^{(\mathrm{n}+1)+}+\mathrm{OH}^{-}$

$\mathrm{Me}^{(\mathrm{n}+1)+}+\mathrm{ROOH} \rightarrow \mathrm{ROO} \bullet+\mathrm{Me}^{\mathrm{n}+}+\mathrm{H}^{+}$(Wsowicz et al., 2004)

Free radicals which are generated with the decomposition of hydroperoxides, radicals produced from food contaminants are all prooxidants. Additionally, riboflavin and porphyrins pigments which are chlorophyll, hemoglobin and myoglobin and synthetic dyes absorbing UV light energy are possible initiators of photo oxidation (Wsowicz et al., 2004). 
The studies carried out so far have indicated the effect of temperature, relative humidity, exposure of oxygen, namely the storage conditions on lipid peroxidation (Soyer, Özalp, Dalmış, \& Bilgin, 2010; Marinova et al., 2012; Stewart \& Bewley, 1980; Kingston, Monahan, Buckley, \& Lynch, 1998; Naz, Sheikh, Siddiqi, \& Asad Sayeed, 2004). When different storage temperatures are used for different types of oils, oxidative changes were reported as polyunsaturated oils showed the worse oxidative stability (Marinova et al., 2012). Naz et al. (2004) concluded their study that low concentrations of oxygen is enough to initiate the lipid peroxidation and the prevention of air and light exposure is essential to increase the oxidative stability.

Antioxidants are the inhibitors of oxidation mechanism. Antioxidants create a defense mechanism, effective on eliminating oxidative stresses and preventing cell destruction. According to their role in the mechanism, they are divided in two as primary and secondary antioxidants. Primary antioxidants break the free radical chain by donating hydrogen to lipid radicals (Niki et al., 2005; Wsowicz et al., 2004).

$\mathrm{ROO} \bullet+\mathrm{AH} \rightarrow \mathrm{ROOH}+\mathrm{A} \bullet \quad$ (Wsowicz et al., 2004)

Furthermore, the stability of antioxidant radical for the delocalization of their unpaired electron in the ring prevents the reaction with fatty acids, makes it able to interact with lipid radicals and inhibit the chain reaction (Wsowicz et al., 2004).

$\mathrm{ROO} \bullet+\mathrm{A} \bullet \rightarrow \mathrm{ROOA} \quad$ (Wsowicz et al., 2004)

Secondary antioxidants are not directly involved in chain breaking. Instead, they prevent the oxidation by scavenging metals and oxygen, reducing metals, capturing singlet oxygen and recovering the primary antioxidants (Wsowicz et al., 2004).

Tocopherols, BHT, BHA and PG are the main antioxidants. $\alpha$-tocopherol is the most important antioxidant in chain breaking of human lipids. Ascorbic acid is an antioxidant acting as metal and oxygen scavenger, reducing and recovering agent. The examples of metal scavengers and reducers are citric acid, phosphoric acid 
and EDTA. Ascorbyl palmitate and sulfites as oxygen scavengers and reducing agents, carotenoids acting for depressing oxygen are other examples of antioxidants (Wsowicz et al., 2004; Halliwell, 1993; Report, 1992).

There are many studies showing the positive effects of antioxidants on the inhibition of lipid peroxidation (Özalp Özen, Eren, Pala, Özmen, \& Soyer, 2011; Mielnik, Olsen, Vogt, Adeline, \& Skrede, 2006; Lin et al., 1989; Faustman et al., 1989; Kingston et al., 1998; Güntensperger, Hämmerli-Meier, \& Escher, 2006). Lin et al. (1989), Faustman et al. (1989) and Kingston et al. (1998) reported in their studies that $\alpha$-tocopherol has a significant effect to reduce the lipid oxidation. Phenolic from plant extracts are proved to increase the oxidative stability of foods (Mielnik et al., 2006; Güntensperger et al., 2006; Özalp Özen et al., 2011).

\section{$1.4 \quad$ Functional Foods}

Functional food is a conventional food product produced to provide physiological benefits and to reduce risk of diseases by its fortified nutrients additionally to naturally occurring substances. Functional food does not have the effects of therapy preventing the diseases like pharmaceuticals. Functional food products differ from the nutraceuticals and dietary supplements of its being a part of daily $\operatorname{diet}$ (Saarela, 2011).

In order to set the above criteria of functional food on a scientific base, three main claims developed in 1996 by International Life Science Institute (ILSI Europe) were declared in European Commission Concerted Action on Functional Food Science in Europe (FUFOSE) and achieved the European Consensus on 'Scientific Concepts of Functional Foods' in 1998. These claims state the requirements of scientific evidence for the positive effects of food on health promoting functions, relevant science research of related functions and compromise on the details of implementations needed to carry out functional variations on food (Saarela, 2011; Hamaker, 2007). 
Increasing concerns on human health have leaded the development of functional foods. The consumer interest on behalf of functional foods due to its health promoting and disease preventing attributes as well as being good sources of nutrients has brought about necessity for improvements of functional foods. As improvements in functional foods proceed, besides being healthy, sensory properties, suitability for use, being natural have become necessary due to consumer perception. This requirement has brought the use of many various ingredients, additives and high processing techniques in the production of functional foods which create concerns on their consumption, thus, regulations have been developed to control the production and marketing of functional foods (Saarela, 2011).

The enhancement of gastrointestinal functions, defense mechanism for reactive substances creating oxidative stress and psychological and behavioral functions have been the main targets aimed in the development of functional foods (Saarela, 2011). Probiotics are functional derivatives to be used in functional foods in order to enhance the gastrointestinal functions. Vitamins, most importantly tocopherols, ascorbic acid, carotenoids, and polyphenols are main substitutes for functional foods to inhibit oxidative stress. Psychological and behavioral functions are thought to be improved by macronutrients such as fat substitutes and sweeteners, caffeine as cognitive performance improver, amino acids such as tryptophan and tyrosine as reducers for tendency to sleep and $\beta$-endorphins as pain killers (Saarela, 2011). There are many studies showing the beneficial effects of probiotics on the treatment of acute gastroenteritis as cited by Saarela (2011) as significant reduction on incidence of gastroenteritis (Bruzzese et al. 2009) by the infant formula supplemented with probiotics and generation of hypocholesterolaemic effect of probiotics on lipid metabolism (Mann, 1977). Dietary fiber obtained from cereals were also reported as effective on the reduction of coronary heart disease (Shibamoto, Kazuki, Fereidoon, \& Chi-Tang, 2008).

In the production of functional foods, safety regulations are needed to be adapted as stated in current food regulations. In order to take part in novel foods class, the 
strategy is required to be followed as defined in EU Novel Food Directive that is a regulation for safety. The production of functional food is a research and development issue regarding the relation of diet and health on scientific base (Saarela, 2011). The development in food technology has to be followed for new raw materials, technologies, safety regulations to integrate into functional food development to improve the functionality (Saarela, 2011).

\subsection{Microencapsulation}

Microencapsulation is an entrapment process of materials within another material or matrix (Garti \& McClements, 2012). Encapsulation provides the dissociation of the materials from the environment to be released when it is desired. Encapsulated materials could be solid particles, liquid droplets or gas attributing different characteristics of molecular weight, structure, polarity, charge, physical state, density and rheology, and various functionalities as antimicrobial, flavor, color, nutraceutical, enzyme and probiotics (Garti \& McClements, 2012; Risch \& Reineccius, 1995). The matrix formed to coat the materials is a delivery system that could be composed of proteins, polysaccharides, lipids, water, surfactants and minerals in a homogeneous or heterogeneous state (Garti \& McClements, 2012). The encapsulated material is named as active, core material, fill, payload or internal phase and the encapsulant entrapping the material is named as wall material, carrier, membrane, shell or coating as defined by Risch \& Reineccius (1995).

Microencapsulation process enables the protection of food components providing increased stability, functionality and availability to be incorporated in food, hence helps to improve functional food ingredients of food additives, nutraceuticals and dietary supplements (Risch \& Reineccius, 1995; Garti \& McClements, 2012). In order to design suitable delivery system for encapsulation, active component is needed to be examined for its activity with the environment, process, storage, consumption and delivery system components. Active components can be defined 
by their molecular level which is their molecular weight, structure, flexibility, polarity and electrical charge, physicochemical level which is their physical state, solubility, distribution in solvents, surface activity, rheological properties, optical properties and chemical stability, and biological level which is their bioactivity

with microorganisms, animals or humans. There are many reasons of encapsulating active compounds besides providing improved handling, storage and transportation. Here, main and specific reasons of encapsulation for major food active compounds are explained. Flavors are encapsulated to inhibit the volatilization and chemical degradation of aromas. The aim of encapsulation of antioxidants is to prevent the light and oxygen contact, thereby to inhibit the chemical degradation just as the reasons of the encapsulation of bioactive lipids. Antimicrobials are encapsulated to improve the incorporation of the compound in food, functionality and mask the off-flavors. The reasons to encapsulate bioactive proteins, peptides and amino acids are to prevent the degradation and to trigger the release in desired environment, and to protect from unwanted off-flavors and taste (Garti \& McClements, 2012). In order to implement these functions, appropriate delivery systems are generated.

\subsubsection{Encapsulation Matrix}

The components of delivery system, namely encapsulation matrix have to be accepted as food grade and safe. The encapsulation matrix needs to be compatible with the active ingredient not to prevent its functionality. The encapsulation matrix should be generated according to perform the required functions of active components mentioned in previous section. In order to produce a useful encapsulation matrix, encapsulating materials should have good emulsifying and gel forming abilities, and create viscous structure (Augustin \& Hemar, 2009; Garti $\&$ McClements, 2012). The capability of designed delivery system to encapsulate the ingredient is important for the efficiency of the system and to release the ingredient at the targeted site for its bioavailability (Garti \& McClements, 2012). 
Encapsulation matrix for food ingredients can be generated by liposomes, emulsions, coacervates, powder particles, gels and molecular complexes. Molecular complexes are formed by the interaction of the host compound that is the encapsulating material with the active ingredient (Sagalowicz \& Leser, 2010; Garti \& McClements, 2012). Encapsulating material could be proteins, carbohydrates, lipids and emulsifiers (Table 1.5) (Garti \& McClements, 2012).

Proteins are extensively used valuable food ingredients for their functionality in forming stable food emulsions (Dickinson, 1999). They are amphiphilic compounds and interact with hydrophilic and lipophilic ingredients. Their aggregation and gelation develops matrix networks together with other ingredients (Augustin \& Hemar, 2009). Proteins form a stable emulsion by assembling at the interfaces and adsorbing the oil droplets and gas bubbles. Proteins are surface active ingredients since they have amphiphilic molecules possessing ionic, polar and nonpolar regions (Dickinson, 1999). Additionally to their amphiphilic and electrostatic interactions, hydrogen bonding and van der Waals' interactions are also effective in forming three dimensional networks (Augustin \& Hemar, 2009). Milk proteins, caseins and whey proteins, are widely used encapsulating agents in food industry due to their nutritional properties and common encapsulant materials in food industry (Singh, 2011; Augustin \& Hemar, 2009). Caseins form flexible and disordered structure at the interface; on the other hand whey proteins form dense globular structure. The flexible and disordered structure of casein has parts called as 'trains' in contact with the surface and as 'tails' going through the aqueous phase forming a complex monolayer. Globular proteins are compact and defined as two dimensional highly interactive particles. Low level of assemblies of globular proteins could be more unfolded (Dickinson, 2001). Casein and whey proteins have been also proved to be effective in protection from lipid oxidation (Singh, 2011).

The lipid oxidation has been reported to be reduced by positively charged proteins which include the milk proteins and the caseins were found to have better antioxidant property than whey proteins (Singh, 2011). 
Table 1.5 Coating materials in encapsulation (Garti \& McClements, 2012)

\begin{tabular}{|c|c|}
\hline Material class & Examples \\
\hline Proteins & $\begin{array}{l}\text { Albumin, caseinates, gelatin, gluten, peptides, soy protein, } \\
\text { pea proteins, whey proteins, zein }\end{array}$ \\
\hline Simple & Fructose, galactose, glucose, maltose, sucrose \\
\hline Carbohydrates/gums & $\begin{array}{l}\text { Chitosan, corn syrup solids, cyclodextrin, dried glucose } \\
\text { syrup, maltodextrins, starches and modified starch } \\
\text { derivatives, starches, carrageenan, gum arabic, pectin, } \\
\text { gellan gum }\end{array}$ \\
\hline Lipids & $\begin{array}{l}\text { Edible fats and oils, fractionated fats, hardened fats, } \\
\text { beeswax }\end{array}$ \\
\hline Emulsifiers & $\begin{array}{l}\text { Mono- and di-glycerides, lecithin, liposomes, food-grade } \\
\text { surfactants }\end{array}$ \\
\hline Cellulose & $\begin{array}{l}\text { Acetylcellulose, carboxymethyl cellulose, cellulose } \\
\text { acetate butyrate, cellulose acetate phthalate, ethyl } \\
\text { cellulose, meyhyl cellulose }\end{array}$ \\
\hline
\end{tabular}

Hogan, McNamee, O'Riordan and O'Sullivan (2001) studied microencapsulating properties of sodium caseinate and reported the effects of different oil:protein ratios on microencapsulation efficiency of soy oil as increased oil:protein ratio from 0.25 to 3.0 has decreased the efficiency for about $70 \%$, which was related to the decrease of protein load. Caseinate as a matrix forming material rather than being a surfactant in this study showed high viscosity values. High viscosity values indicate the higher volumes of dispersed phase and the concentration of total solids in the emulsion affecting the formation of the thickness of semipermeable wall structure, drying properties, migration of core material to the 
surface of the particle and the particle size (Hogan, McNamee, O'Riordan, \& O'Sullivan, 2001a). Another study conducted by Kagami et al. (2003) showed the higher emulsification properties of sodium caseinate over whey protein isolate as supported by the results of interfacial tension measurements of emulsions prepared by each of these encapsulating proteins. In the same study, the oxidative stability tests shows that microcapsules prepared by sodium caseinate was higher than whey protein isolate which was related to the higher gas permeability of whey protein isolate wall material (Kagami et al., 2003). Augustin and Hemar (2009) have reported the positive effect of carbohydrate attached to protein wall materials on improving colloidal stability. Another advantage is that carbohydrates improve the drying characteristics of wall material. The improvement of drying characteristics of wall material by carbohydrates is supported by the fact that they change the glass transition temperature of wall material and provides the accelerated dry crust formation on the droplets (Aghbashlo, Mobli, Madadlou, \& Rafiee, 2012). Various researchers have reported the improved encapsulating ability of carbohydrate attached protein wall materials (Vignolles, Jeantet, Lopez, \& Schuck, 2007; Jayasundera, Adhikari, Aldred, \& Ghandi, 2009; Vega \& Roos, 2006). Hogan, McNamee, O’Riordan, and O'Sullivan (2001a) has studied the emulsification and microencapsulation properties of sodium caseinate blended with carbohydrates of different dextrose equivalent ratios on encapsulating soya oil and concluded that the efficiency of microencapsulation increased with increased dextrose equivalent.

Carbohydrates are frequently used encapsulating materials. Their structural properties of forming glassy solids make them useful encapsulating constituents in delivery systems. Maltodextrins constitute solution of high solid concentrations at low viscosity which enables to have high solids entrapping the active material when the system is dehydrated. Their higher glass transition temperature provides reduced stickiness while drying which helps to form a structural integrity. Carbohydrates have good stabilizing abilities whereas they do not have emulsifying properties, therefore, they should be used in combination with other surface active materials to form encapsulating system. As an exception, among 
the carbohydrates, gum arabic could provide stable structure for its being surface active component (Augustin \& Hemar, 2009). Polysaccharides generate gels upon forming encapsulating system, yet not at higher concentrations than formed by proteins. The formation of gel network depends on the chemical structure, molecular weight, the degree of branching and functional groups of carbohydrate. Chitosan is one of the polysaccharides, a cationic polymer, used as a wall material in encapsulation and there are studies carried out on encapsulation of oils and lipophilic drugs with chitosan so far (Klaypradit \& Huang, 2008; Sonvico et al., 2006; Klinkesorn, Sophanodora, Chinachoti, McClements, \& Ecker, 2005; Li et al., 2013). Aghbashlo et al. (2012) the wall material effect on encapsulation of fish oil and reported that incorporation of carbohydrates lead to change in drying properties and a study of microencapsulation of extra virgin olive oil carried out by Calvo, Hernández, Lozano, and González-Gómez, (2010) was concluded as use of proteins and carbohydrates combinations for encapsulation results in better encapsulation efficiency. Calvo, Castaño, Lozano, \& González-Gómez (2012) had similar findings supporting the positive effect of protein incorporated wall materials as yielding protective properties during storage and enhancing shelf life of microcapsules.

\subsubsection{Emulsion Homogenization}

Emulsions are thermodynamically unstable systems of immiscible liquids mixture dispersing of one in another. The generation of emulsion by immiscible liquids is carried out by homogenization process. There are several types of homogenizers developed for food emulsion applications. High-speed blenders, colloid mills, high-pressure valve homogenizers, ultrasonic homogenizers, microfluidization, membrane homogenizers are the most important homogenizers used in food industry (McClements, 2004). High-speed blenders, ultrasonic homogenizer and microfluidizer will be briefly examined for this study. 


\subsubsection{High Speed Blenders}

High speed blenders provide direct homogenization of liquids. They are most widely used for homogenization of oil and aqueous phases. The agitation is provided by a stirrer rotating at high speeds. The rotation induces the disruption of the interface, mixture of immiscible liquids and breakage of droplets by means of velocity gradients of longitudinal, rotational and radial, which are generated by the blades, in liquids (McClements, 2004).

High speed blenders are mostly used for the preparation of pre-emulsions. Jafari, $\mathrm{He}$, \& Bhandari (2006) reported the resulting particle size of emulsion of dlimonene and fish oil prepared by high speed blender at the highest speed for 10 min prior to microfluidization as large as $3760 \mathrm{~nm}$ in their study. This value could be reduced by use of surfactants, yet it is not close to the resulted values of droplet sizes achieved by further homogenization (Jafari et al., 2006b). The comparison results of the different homogenization processes of high speed blender, microfluidizer and ultrasonic homogenizer revealed that high speed blender could create emulsion particle size as small as microfluidizer (Moreau, Kim, Decker, \& McClements, 2003).

\subsubsection{Ultrasonic Homogenizer}

Ultrasonic homogenization is achieved by the ultrasonic waves at high intensity generated by ultrasonic homogenizers. The dispersion of liquids is derived by the cavitation and turbulent effects produced by means of ultrasonic waves (McClements, 2004). Cavitation is the main effect of ultrasonication on emulsification. Cavitation is the collapse of the bubbles at the interface of dispersed and continuous phases (Rahman, 2007). The widely used method for generation of high intensity ultrasonic waves in research laboratories is

piezoelectric transducers. The transducer is composed of a piezoelectric crystal 
covered by a metal case. The piezoelectric crystal is oscillated to produce ultrasonic wave by a high intensity electric wave generated to the transducer. The ultrasonic wave is distributed towards the liquid from the tip of the transducer, then intense pressure and shear gradients are produced by cavitation causing the dispersion of liquids and breakage of droplets (McClements, 2004).

The study conducted by Leong, Wooster, Kentish, \& Ashokkumar (2009) reported the ultrasound effect on nanoemulsion formation of triglyceride oil in water which has the particle size of $40 \mathrm{~nm}$ with regards to the positive effects of compounds in emulsion. Gaikwad \& Pandit (2008) studied the emulsification by ultrasound assistance of different types of oil and related the irradiation time and power with the droplet size. Increased power and time of irradiation caused the decrease in droplet size varying for different types of oils. It was observed that lower power values resulted in coalescence of droplets (Gaikwad \& Pandit, 2008). Kentish et al. (2008) also reported the effect of power level on coalescence and bubble formation and the results derived an optimum value for power and time levels. Another study shows the time dependence of ultrasonication process for emulsification of oil as no significant change after 5 min operation (Cucheval \& Chow, 2008).

\subsubsection{Microfluidizer}

Microfluidizer is composed of a fluid inlet, pump and an interaction chamber. The mixture of fluids is fed into the device through the fluid inlet and fluids flow through the channels in the interaction chamber and interact with each other. The velocity of fluid flow across the channels are ensured by means of pump and increased to high levels to make them collide with each other (McClements, 2004). The homogenization principle of microfluidization is to go beyond the energy barrier by the generated momentum and turbulence in microchannels (Rahman, 2007). High velocity rates cease the disruption of fluids to merge into each other and form smaller sized droplets. The microfluidization can be used for 
both the reduction of droplet size of an emulsion and production of an emulsion feeding the liquids from each of two channels (McClements, 2004).

Many studies regarding the microfluidization in encapsulation of oils have been performed so far. The resulting effect of microfluidization applied to prepare oil in water emulsion on reduction of particle size was reported as increasing pressure and cycles of treatment leaded the decrease of particle size to an optimum level after which the increase of these parameters leaded negative results (Han et al., 2014)(Jafari et al., 2006b). Jafari et al., (2006) studied different process parameters of pressure and number of cycles. In this study, D32 value of particle size was reduced when the pressure was increased from 35 to $70 \mathrm{MPa}$; however, above $70 \mathrm{MPa}$ this value increased (Jafari et al., 2006b). Jafari, He, \& Bhandari (2007) compared four different homogenizers; a normal mixer, a colloid mill, microfluidizer, ultrasonic homogenizer, and concluded that microfluidization created the smallest emulsion droplet size and narrower distribution than ultrasonication. Another comparison of microfluidization and ultrasonication in preparation of fish oil emulsion also shows that the surface oil content is lower in microfluidized emulsion system, and it has the smaller droplet size. It was also stated according to the results of experiments that the emulsification significantly affects the efficiency of microencapsulation (Jafari, Assadpoor, Bhandari, \& He, 2008).

\subsubsection{Encapsulation Techniques}

There are many encapsulation techniques used for food ingredients and in most of them the basis of encapsulation is drying process (Garti \& McClements, 2012). The encapsulation technique to be used for the production of microcapsules should be chosen appropriate for the physicochemical properties of active and wall materials in the matrix system (Augustin \& Hemar, 2009). The most common techniques are spray drying and freeze drying processes since these processes are simple to apply. They are advantageous in reducing the volume of 
product, storage space and hence the cost of transportation. In addition, the production of dried microcapsules provide higher stability due to the low moisture content and powder form eases the fortification of microcapsules into other food substances (Garti \& McClements, 2012).

\subsubsection{Spray Drying}

Spray drying is one of the oldest and well-established technique used in food industry since the end of 1950s (Garti \& McClements, 2012; Gouin, 2004). The operation is a continuous process provided with good flow availability. Although spray drying is presented as a suggested technique for heat sensitive materials supported by the short period of drying process and surface removal of moisture of the droplets providing the materials to stay cool during drying, it is not applicable that the possible heat inducing changes could happen in the material (Augustin \& Hemar, 2009; Garti \& McClements, 2012).

The operation in spray drying consists of feeding the encapsulation matrix, atomization of the emulsion in microdroplets, evaporation of droplets and recovery of microcapsules. After the preparation of emulsion with the appropriate ingredients compatible to the core material as covered in previous sections, the emulsion is fed to the equipment and passed through the atomizers. Widely used atomizers are pressure, centrifugal (wheel) and pneumatic (two-fluid) atomizers. The uniformity and the homogeneity are the effective characteristics of atomizers on the particle size of microcapsules. Atomization increases contact area for heat transfer between the drying air and liquid droplets. Several different parameters affect the efficiency of the process, such as encapsulating solid compound as active material, emulsions having high viscosity and the size of atomized liquid droplets. Solid matter and viscous emulsions could prevent atomizing by blocking the atomizers. The size of droplets directly related to the change in drying time and particle size is affected by the surface tension and viscosity of emulsion as 
well as pressure drop in the nozzle and spraying velocity (Garti \& McClements, 2012).

The evaporation takes place in drying chamber via counter or co-current drying. Counter-current drying is not applicable for sensitive materials since the drying temperature is high. The temperature value of inlet air varies between $150^{\circ} \mathrm{C}$ and $220^{\circ} \mathrm{C}$ which are very effective on instantaneous drying of liquid droplets providing lower powder temperatures varying between $50^{\circ} \mathrm{C}$ and $80^{\circ} \mathrm{C}$ than outlet air. This temperature value of powder protects the material from thermal degradation and the core material tried to be kept below $40^{\circ} \mathrm{C}$ by means of short evaporation time to discard any thermal damage. Therefore, optimum inlet and outlet air temperature should be attained considering the sensitivity of both active and wall materials and microcapsules (Garti \& McClements, 2012).

There are some studies of oil encapsulation by spray drying technique. Klinkesorn, Sophanodora, Chinachoti, Decker, \& McClements (2006) studied the characterization of spray dried tuna oil and obtained 5 to $30 \mu \mathrm{m}$ size microcapsules stable at 165 to $195^{\circ} \mathrm{C}$ drying temperature attributing low moisture content, high oil retention values and rapid water dispersibility. Partanen, Yoshii, Kallio, Yang, \& Forssell (2002) studied the oxidative stability of sea buckthorn kernel oil encapsulated by spray dying and investigated the relation of particle droplet size with the retention of volatiles. Another study of microencapsulation of linseed oil by spray drying showed different results on surface structure of microcapsules prepared by various wall materials affecting the yield and efficiency of spray dried microcapsules (Gallardo et al., 2013). The study comparing the spray drying and freeze drying processes showed that although the efficiency of microcapsules processed with each technique is similar, oxidative stability of freeze dried particles were found to be higher than spray dried, which was explained by the destabilization and coalescence of irregular fat globules which are easily prone to oxidation. The reason is reported as the bigger globules possess low amount of hydrophobic maltodextrin material which favors the interaction of hydrophobic oxygen (Dzondo-Gadet, Nzikou, Etoumongo, Linder, \& Desobry, 2005). 


\subsubsection{Freeze Drying}

Freeze drying operation is composed of two steps which are freezing of the medium to be dried and the sublimation of the frozen medium at low temperature and pressure. The drying process consists three stages of freezing, primary drying which is main drying and sublimation, lastly secondary drying which is desorption. After the encapsulation matrix is prepared, it is cooled and crystallized. During the primary drying, the ice is sublimated to water vapor and water vapor is delivered to the drying chamber to be condensed or absorbed by condenser coil. Secondary drying provides the removal of adsorbed water, which is unfrozen bound water (Garti \& McClements, 2012).

As mentioned in spray drying technique, the suitable wall material selection for core ingredient is a significant step, considering the operation used, to maintain desired properties of core ingredients and form of microcapsules. Freezing and dehydration could lead stresses on the core materials, so the wall materials are better to be functional as protecting the core material from cell damage upon freezing (Garti \& McClements, 2012).

The process conditions affect the quality of the product. Freezing cause the changes on the texture and the morphology of the dried material. As the cooling rate of matrix is accelerated, the size of ice crystals become smaller providing lowered stress on core materials, yet this could also lead to destabilization of nanoparticles and hence aggregation of dried particles when dispersed after drying as cited by (Garti \& McClements, 2012). Therefore, it is suggested to freeze the matrix at $-70^{\circ} \mathrm{C}$ in a freezer slowly. Due to the operating conditions at low temperature, freeze drying is advantageous on the encapsulation of heat sensitive materials (Garti \& McClements, 2012).

Encapsulation by freeze drying has been used for oil encapsulation by several researchers (Sen Gupta, Ghosh, Maiti, \& Ghosh, 2012; Calvo et al., 2012; Silva, Coelho, Calado, \& Rocha-Leão, 2013; Heinzelmann \& Franke, 1999; Heinzelmann \& Franke, 2000; Heinzelmann, Franke, Velasco, \& Márquez-Ruiz, 
2000) and many of them include the enhancement of oxidative stability during storage. Sen Gupta et al. (2012) preferred to use freeze drying to encapsulate pomegranate seed oil due to low temperatures and having effective results for sensitive materials. Calvo et al. (2012) also used freeze drying for encapsulation of refined olive oil due to the higher resistance of freeze dried particles than spray dried particles to oxidation. The study showed that better results were obtained by the effective barrier preventing the oxidative damage and the stability of the capsules were ensured due to lower humidity and water activity achieved by encapsulation process (Calvo et al., 2012). The oxidative stability of encapsulated fish oil by freeze drying was also covered by Heinzelmann \& Franke (1999), Heinzelmann \& Franke (2000) and Heinzelmann et al. (2000), and their results showed promising effect of freeze drying on enhancement of oxidative stability of fish oil. It was indicated that the effect of coating material should be considered on evaluating the effective encapsulation as well as the technique used. Additionally it was stated that the efficiency of microcapsules was not enough alone to be related to the storage (Heinzelmann et al., 2000; Heinzelmann \& Franke, 1999).

\subsection{Objectives of the Study}

Concerns for diseases make people to consume foods fortified with nutrients. Wheat germ oil is known as the highest source of $\alpha$-tocopherol. As a natural antioxidant, $\alpha$-tocopherol protects the cell membrane from peroxidation and help to reduce the risk of vascular diseases by inhibition of LDL oxidation. In addition to $\alpha$-tocopherol, wheat germ oil contains high amounts of bioactive compounds including other tocopherol derivatives, phytosterols, polycosanols, thiamin, riboflavin and niacin improving body functions. However, it is easily oxidized in free form.

Encapsulation is a compromising technique used to protect active materials against unsuitable environmental and processing conditions. This technique 
provides to maintain the characteristics of material by isolating it from the environment. By this method, the undesired odor and taste could be masked; volatiles could be protected from evaporation and the oxidation could be prevented. The release of material could be controlled and hence the stability of the material is maintained, which increases the shelf life of the material.

There are few studies on encapsulation of wheat germ oil in the literature.

The main objective of this study was to improve the encapsulation efficiency of wheat germ oil by employing different coating materials and homogenization techniques. Another objective was to examine the storage stability of encapsulated wheat germ oil. The effects of different homogenization techniques and coating materials on particle size of microcapsules were also investigated. 


\section{MATERIALS AND METHODS}

\subsection{Materials}

Wheat germ oil (WGO), maltodextrin (MD) having dextrose equivalent value of 4-7, chitosan (CS), gum arabic (GA) and casein sodium salt from bovine milk $(\mathrm{NaCa})$ were purchased from Sigma Aldrich Chemical Co. (St. Louis, MO, USA). The chemicals dipotassium phosphate $\left(\mathrm{K}_{2} \mathrm{HPO}_{4}\right)$, potassium dihydrogen phosphate $\left(\mathrm{KH}_{2} \mathrm{PO}_{4}\right)$, glacial acetic acid, hexane, magnesium chloride $\left(\mathrm{MgCl}_{2}\right)$, chloroform, potassium iodide, sodium thiosulfate, starch, isooctane (2, 2-,4trimethylpentane), p-anisidine, methanol for HPLC, acetonitrile for HPLC and DL- $\alpha$-tocopherol acetate were also purchased from Sigma-Aldrich Chemical Co. (St. Louis, MO, USA). Whey protein concentrate (WPC) which contains 80\% protein was supplied from Tunçkaya Kimyevi Maddeler (Tuzla, İstanbul).

\subsection{Microencapsulation of Wheat Germ Oil}

\subsubsection{Preparation of Coating Materials}

The maltodextrin (MD) and sodium salt of casein $(\mathrm{NaCa})$ solutions were prepared one day before the emulsion preparation. The MD and $\mathrm{NaCa}$ were dissolved in distilled water at $10 \%$ and $30 \%$ concentration by weight, respectively. The solutions were mixed by magnetic stirrer (Heidolph MR 3001 K, Heidolph Instruments $\mathrm{GmbH} \& \mathrm{Co}$, Schwabach, Germany) and left in the shaking bath at $25^{\circ} \mathrm{C}$ and $90 \mathrm{rpm}$ over one night for complete dissolution.

Whey protein concentrate (WPC) solutions were prepared in 1\%, 10\%, 30\% and $40 \%$ concentrations by weight, dissolving in buffer solution for $5 \mathrm{~min}$ by the 
magnetic stirrer and left in the shaking bath at $25^{\circ} \mathrm{C}$ and $90 \mathrm{rpm}$ over one night for complete dissolution. The buffer solution was prepared by using dipotassium phosphate $\left(\mathrm{K}_{2} \mathrm{HPO}_{4}\right)$ and potassium dihydrogen phosphate $\left(\mathrm{KH}_{2} \mathrm{PO}_{4}\right)$, using the method adapted from Kuhlmann, (2006) (Turasan, 2014). Firstly, 1 M solutions of each chemical were prepared. After that, in order to get $1 \mathrm{M}$ of $100 \mathrm{ml}$ buffer

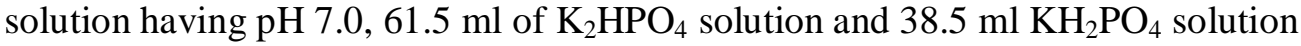
were mixed. Then, the solution was diluted to $5 \mathrm{mM}$.

Gum arabic (GA) solution was prepared at $10 \%$ concentration by weight in distilled water. Chitosan (CS) was dissolved in $0.25 \%$ aqueous acetic acid solution to obtain $1 \%$ concentration 2 hours prior to emulsion preparation for complete dissolution.

\subsubsection{Preparation of Emulsions}

After the coating materials were prepared, they were weighed in a $250 \mathrm{ml}$ beaker and mixed to obtain $80 \mathrm{~g}$ coating material solution of ratios MD:WPC-1:3, MD:WPC-1:4, MD:GA-1:3, MD:CS-10:1, WPC:CS-10:1, WPC:CS-1:1, MD:NaCa-1:3. Wheat germ oil was added to coating material solution to obtain emulsion with core to coating ratio of 1:8.

The coating and core material mixture was first pre-homogenized in high-speed blender (IKA T25 digital Ultra-Turrax, Selangor, Malaysia) at $8000 \mathrm{rpm}$ for 5 min. Then, for main emulsion preparation, the pre-emulsions were homogenized in Ultrasonic Homogenizer (Sonic Ruptor 400, OMNI International the Homogenizer Company, Georgia, USA) for $15 \min$ at $40 \mathrm{kHz}$ using $50 \%$ pulse. These parameters were fixed according to preliminary experiments. In order to prevent the temperature rise of the emulsion, the beakers were kept in water baths at $4^{\circ} \mathrm{C}$ during ultrasonic homogenization.

In the preparation of $\mathrm{MD}: \mathrm{NaCa}$ pre-emulsion at a ratio of $1: 3$, different homogenization techniques, which were silent crusher (Heidolph Silent Crusher 
S, Schwabach, Germany) and microfluidizer (Nano-dispenser NL-100, Daedeok, South Korea) were used. The silent crusher was performed at 75,000 rpm for 15 min. In order to prevent the temperature rise in emulsion, the beakers were kept in ice bath during homogenization. Microfluidization was performed at $500 \mathrm{MPa}$ for 1,2 and 3 cycles.

After homogenization, emulsions were put into $250 \mathrm{ml}$ beakers so as to be half filled and then frozen. Effects of freezing temperatures on encapsulation efficiency were studied by using freezers at $-18^{\circ} \mathrm{C}$ (BEKO D 8340 SM, Eskişehir, Turkey) and $-80^{\circ} \mathrm{C}$ (CL Hetofrig, Birkrod, Denmark).

\subsubsection{Freeze Drying}

Frozen emulsions were dried under vacuum in freeze drier (Christ, Alpha 2-4 LD plus, Osterode am Harz, Germany) for 48 hours at $-50^{\circ} \mathrm{C}$ and at 0.019 mbar. After drying, dried products were grinded into powders by a glass rod.

\subsection{Analysis of Emulsions and Microcapsules}

\subsubsection{Efficiency Analyses of Microcapsules}

The encapsulation efficiency of microcapsules indicates the ratio of oil at the surface of the microcapsules to the encapsulated oil. The method to measure the surface oil of microcapsules was adapted from Calvo et al. (2010) and MillqvistFureby (2003). In a beaker, $5 \mathrm{~g}$ of microcapsules were weighed. The powder was washed with $50 \mathrm{ml}$ hexane and mixed by the magnetic mixer at $200 \mathrm{rpm}$ for $60 \mathrm{~s}$; then, it was left to stand for $10 \mathrm{~min}$. After $10 \mathrm{~min}$, the mixture was filtered through filter paper (No. 41, Whatman, Maidstone, UK). The powder residue was again washed with $2 \times 5 \mathrm{ml}$ hexane. The solvent mixture was allowed to evaporate 
under fume hood in a beaker. When the solvent evaporation was completed, the extracted oil was placed in an oven at $105^{\circ} \mathrm{C}$ for complete evaporation of solvent until a constant weight was achieved which took about 1 hour. The amount of surface oil was calculated by subtracting the weight of the empty beaker from the weight of the beaker containing surface oil.

The total oil content was measured by Soxhlet extraction of microcapsules (Calvo et al., 2010). Extraction was performed using $250 \mathrm{ml}$ hexane for $5 \mathrm{~g}$ of powder for $4 \mathrm{~h}$. The solvent in the mixture collected in the volumetric flask was distilled by a distillation column. The concentrated mixture was transferred to a beaker and further evaporated under fume hood; then dried in the oven at $105^{\circ} \mathrm{C}$ until constant weight was achieved. The amount of total oil was calculated by subtracting the weight of the empty beaker from weight of beaker containing oil.

The encapsulation efficiency was calculated by equation (2.1) (Calvo et al., 2010):

Encapsulation efficiency $(\%)=\frac{(\text { Total oil content }- \text { Surface oil content })}{(\text { Total oil content })} \times 100(2.1)$

\subsubsection{Particle Size Analyses of Emulsions}

Particle size of microcapsules was measured by laser diffraction particle size analyzer (Malvern Mastersizer 3000, Malvern Instruments Limited, Worcestershire, U.K.). Measurement was performed by using the particle refractive index of 1.38 measured by refractometer and dispersant refractive index of 1.33 measured by UV/VIS spectrometer T 70, (PG Instruments LTD, UK).

Emulsions prepared by $\mathrm{MD}$ and $\mathrm{NaCa}$ at a ratio of 1:3 were homogenized with three different homogenization techniques. In high pressure homogenization, the effect of number of cycles was also studied. 
The particle size of emulsions was described by Sauter mean diameter, D32, and span, the polydispersity of size distribution. D32 is the measurement of expressing the main disposition of particle and it is calculated by the equation (2.2);

$$
\mathrm{D} 32=\frac{\sum \mathrm{n}_{\mathrm{i}} \mathrm{d}_{\mathrm{i}}^{3}}{\sum \mathrm{n}_{\mathrm{i}} \mathrm{d}_{\mathrm{i}}^{2}}
$$

Where, $d_{i}$ stands for the diameter of the particles in each size class and $n_{i}$ states the number of particles in each size class per unit volume of emulsion. Span is the measurement of the width of the distribution and it is calculated by the equation (2.3);

$$
\text { Span }=\frac{[\mathrm{d}(0.9)-\mathrm{d}(0.1)]}{\mathrm{d}(0.5)}
$$

Where, $\mathrm{d}(0.9), \mathrm{d}(0.5)$ and $\mathrm{d}(0.1)$ are the $90 \%, 50 \%$ and $10 \%$ cumulative sizes of particle diameters respectively (McClements, 2004; Chew, Chan, \& Pharmacy, 2006).

\subsection{Storage Stability of Microcapsules}

The microcapsules prepared with $\mathrm{MD}$ and $\mathrm{NaCa}$ at a ratio of 1:3 using microfluidization were investigated for their storage stability at two different temperatures of $15^{\circ} \mathrm{C}$ and $45^{\circ} \mathrm{C}$. Saturated magnesium chloride solution $\left(\mathrm{MgCl}_{2}\right)$ was used to prepare the storage environments having relative humidities of $33.3 \pm$ $0.21 \%$ and $31.10 \pm 0.13 \%$ at temperatures $15^{\circ} \mathrm{C}$ and $45^{\circ} \mathrm{C}$, respectively (Greenspan, 1977). Two identical desiccators were used to store the microcapsules at different temperatures. After the saturated salt solution was prepared, it was kept for about 24 hours to reach to equilibrium. The identical 
microcapsules and fresh non-encapsulated wheat germ oil were placed in the desiccators and stored at $15^{\circ} \mathrm{C}$ and $45^{\circ} \mathrm{C}$. The temperature values were controlled and recorded by EBI20 temperature and humidity data logger. For the analyses of peroxide and $\mathrm{p}$-anisidine values, $10 \mathrm{~g}$ of sample stored at $15^{\circ} \mathrm{C}$ were taken every 10 days during 60 days, the microcapsules stored at $45^{\circ} \mathrm{C}$ was though analyzed for every 7 days during 42 days of storage. On the other hand, $\alpha$-tocopherol analyses were done for the first day and in the middle of storage.

The oxidative stability during storage of microcapsules was examined by the analysis of peroxide and p-anisidine values. The oil was extracted from the powder by soxhlet extraction as proposed by Hornero-Méndez, Pérez-Gálvez, \& Mínguez-Mosquera, (2001).

Peroxide value of extracted oil samples was determined by AOCS official method (AOCS, 1998b). $1 \mathrm{~g}$ oil sample was dissolved in $6 \mathrm{ml}$ acetic acid/chloroform solution $(3: 2, \mathrm{v} / \mathrm{v})$. Then, $0.1 \mathrm{ml}$ saturated KI solution was added and mixed occasionally for $1 \mathrm{~min}$. After $1 \mathrm{~min}$ mixing, $6 \mathrm{ml}$ distilled water was added to the solution immediately. The solution was then titrated with $0.01 \mathrm{~N}$ sodium thiosulfate solution until the yellow iodine color disappeared. The volume of sodium thiosulfate solution consumed for titration was recorded. Equation (2.4) was used to calculate the peroxide value;

$$
P V=\frac{(S-B) \times N \times 1000}{W}
$$

Where, PV is the peroxide value (miliequivalents peroxide/1000 $\mathrm{g}$ sample), $\mathrm{S}$ is the volume of sodium thiosulfate solution $(\mathrm{ml})$ consumed during the titration, B is the volume of sodium thiosulfate solution $(\mathrm{ml}), \mathrm{N}$ is the normality of sodium thiosulfate solution and $\mathrm{W}$ is the weight of the oil sample (g) (AOCS, 1998b).

p-Anisidine values was also determined by AOCS official method (AOCS, 1998a). $0.5 \mathrm{~g}$ of extracted oil sample weighed in a volumetric flask and diluted with isooctane (2, 2, 4-trimethylpentane) to $25 \mathrm{ml}$. The absorbance values of 
solution and solvent as blank were measured at $350 \mathrm{~nm}$ in identical cuvettes by using UV/VIS spectrometer T 70, (PG Instruments LTD, Leicestershire, UK). On the other side, $5 \mathrm{ml}$ of solution and $5 \mathrm{ml}$ of solvent were placed in test tubes. $1 \mathrm{ml}$ of p-anisidine reagent prepared by dissolving $0.25 \mathrm{~g}$-anisidine by $100 \mathrm{ml}$ glacial acetic acid was added into the tubes. Each tube was mixed by vortex well and kept for $10 \mathrm{~min}$ for complete reaction. After $10 \mathrm{~min}$, the absorbance values of oil sample and solvent as blank were measured in identical cuvettes. The p-anisidine value was calculated using Equation (2.5);

$$
\mathrm{p}-\mathrm{A} \cdot \mathrm{V} .=\frac{25 \times(1.2 \mathrm{As}-\mathrm{Ab})}{\mathrm{m}}
$$

where p-A.V. is the p-anisidine value, As is the absorbance of oil solution reacted with $\mathrm{p}$-anisidine reagent, $\mathrm{Ab}$ is the absorbance of oil solution and $\mathrm{m}$ is the mass of the oil sample $(\mathrm{g})$.

Totox value was also calculated according to equation (2.6) (Semb, 2012);

$$
\text { Totox value }=2 \times \text { P.V.+ p-A.V. }
$$

High performance liquid chromatography (Thermo Finnigan Surveyor HPLC System, Thermo Scientific, San Jose, CA USA) was used for $\alpha$-tocopherol analysis. The HPLC system was composed of liquid chromatography pump (Finnigan Surveyor LC Pump Plus), autosampler (Finnigan Surveyor Autosampler Plus), ultraviolet visible detector (Finnigan Surveyor UV-VIS Plus Detector) and refractive index detector (Finnigan Surveyor RI Plus Detector). The column used for $\alpha$-tocopherol analysis was Varian Chromspher HPLC column (Varian Instruments, Palo Alto, CA, USA) reversed phase of size $150 \mathrm{~mm} \times 4.6$ $\mathrm{mm}$ and $5 \mu \mathrm{m}$ particle size. As mobile phase, acetonitrile:methanol:water (60:38:2) solution was used at flow rate of $1.2 \mathrm{ml} / \mathrm{min}$. The detection of $\alpha$ tocopherol was obtained at a total run time of about 9.5 min under $290 \mathrm{~nm} \mathrm{UV}$. The tray and column temperatures were set to $4^{\circ} \mathrm{C}$ and $30^{\circ} \mathrm{C}$ respectively. Oil 
samples were dissolved in mobile phase and filtered through $0.2 \mu \mathrm{m}$ filter (IsoDisc Syringe-Tip filter, Supelco) (Eisenmenger, 2005). Calibration curve was obtained by diluting DL- $\alpha$-tocopherol acetate in 5 different concentrations of $1 / 1000,10 / 1000,20 / 1000,50 / 1000,100 / 1000$ in mobile phase. The coefficient of regression value of calibration curve $\left(\mathrm{R}^{2}\right)$ was 0.96 (Appendix $\left.A\right)$.

\subsection{Statistical Analysis}

Analysis of variance (ANOVA) was used to identify significant differences between the effiencies of microcapsules, D32 and span values of emulsion particle sizes by using SAS software version 9.1 (SAS Institute Inc., NC, USA). If significant difference was determined, means were compared by using Duncan's Multiple Comparison Test $(\mathrm{p} \leq 0.05)$. 


\section{RESULTS AND DISCUSSION}

\subsection{Encapsulation Efficiency}

Encapsulation efficiency is an indicator for the achievement of the encapsulation process. The effect of different coating materials and homogenization techniques as mentioned in previous sections were evaluated to identify the optimum condition for encapsulation of wheat germ oil at 1:8 core to coating ratio.

First of all, the effect of different freezing temperatures on microencapsulation efficiency was determined in preliminary experiments. Table 3.1 shows the surface oil content of capsules prepared from the emulsions frozen at different temperatures. Encapsulation efficiencies of microcapsules obtained from the emulsions frozen at $-18^{\circ} \mathrm{C}$ and $-80^{\circ} \mathrm{C}$ were found to be $24.12 \%$ and $34.3 \%$, respectively. This finding showed that the increase in freezing rate increased the encapsulation efficiency mainly due to maintaining the emulsion stability as consistent with the statement given by Yin \& Yates (2008). Yin \& Yates, (2008) stated that increase in freezing rate prevented the coalescence, which maintained the emulsion stability. Based on these results, the freezing temperature was chosen as $-80^{\circ} \mathrm{C}$ for further experiments.

The microencapsulation efficiencies of MD:WPC at different ratios and MD:GA combination at 1:3 ratio and homogenized by ultrasonication are seen in Fig.3.1. It was seen that the efficiencies of three combinations were low. The statistical results showed that the efficiencies were not significantly different from each other ( $\mathrm{p} \leq$ 0.05) (Fig.3.1, Table B.1). This is in contrast to the findings of Akhtar \& Dickinson, (2007). They showed that the microencapsulation capability of WPC was more effective than GA due to its emulsifying ability in forming more stable emulsions. Similar efficiency values in the presence of GA and WPC could be explained by the creaming stability of WPC emulsions (Kuhn \& Cunha, 2012). 
Table 3.1 Effect of different freezing temperatures on surface oil content of microcapsules prepared with MD:GA ratio of 1:3

\begin{tabular}{ccc}
\hline $\begin{array}{c}\text { Freezing } \\
\text { temperature }\left({ }^{\circ} \mathbf{C}\right)\end{array}$ & $\begin{array}{c}\text { Surface Oil Content } \\
(\text { g oil/ 100 g capsule) }\end{array}$ & $\begin{array}{c}\text { Encapsulation } \\
\text { efficiency }(\%)\end{array}$ \\
\hline$-18^{\circ} \mathrm{C}$ & $1.61 \pm 0.216$ & $24.12 \pm 3.00$ \\
$-80^{\circ} \mathrm{C}$ & $1.57 \pm 0.052$ & $34.30 \pm 0.42$ \\
\hline
\end{tabular}

Creaming stability is related to the average size of the fat globules and the decrease in size of fat globules increases the stability of emulsion (Desrumaux \& Marcand, 2002). The homogenization of WPC emulsions by ultrasonication was found to be insufficient in decreasing the droplet sizes leading to decrease in creaming stability and accordingly unstable emulsions as also stated by Jafari et al. (2008).

The effect of CS as coating material was also studied and the results of efficiencies of capsules formed by MD:CS and WPC:CS combinations at different concentration and homogenized by US are seen in Fig.3.2. For three combinations of coating material, encapsulation efficiencies were not significantly different ( $\mathrm{p} \leq$ 0.05) (Table B.1). The increase in the WPC concentration in WPC:CS combination did not have any effect on encapsulation efficiency of wheat germ oil. Coating materials of WPC:CS and MD:CS combinations provided similar efficiency values in encapsulation of wheat germ oil. The findings of similar efficiency results with different formulations were supported by the study of Klaypradit \& Huang (2008). In their study Klaypradit \& Huang (2008) stated that the similar results of MD:CS, 10:1 and WPC:CS, 1:1 formulations demonstrated the maximum capability of forming stable emulsion at these combinations. Then, the same results found for different coating concentrations of WPC:CS, 1:1 and MD:CS, 10:1, could be identified with the emulsifying capacity of CS. 


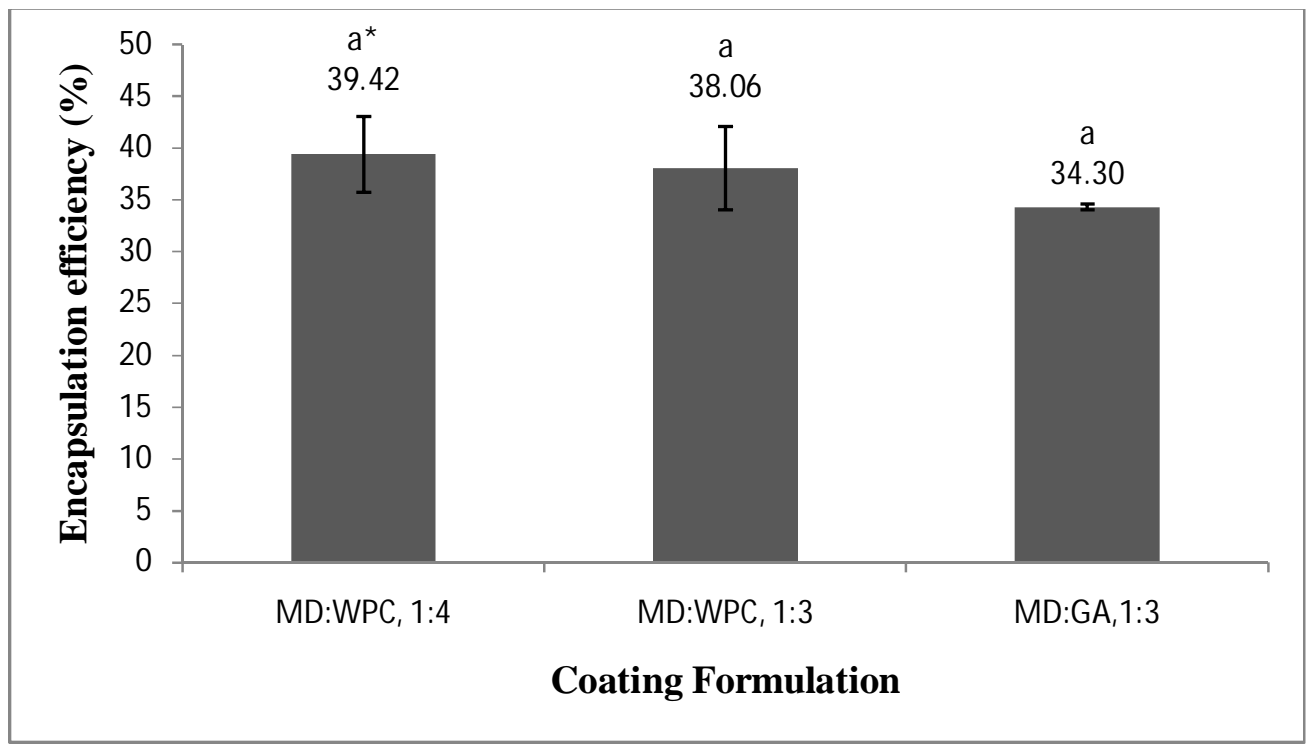

Figure 3.1 Encapsulation efficiencies of microcapsules prepared with MD:GA ratio of 1:3 and MD:WPC at different ratios. *Different letters represent significant difference $(\mathrm{p} \leq 0.05)$

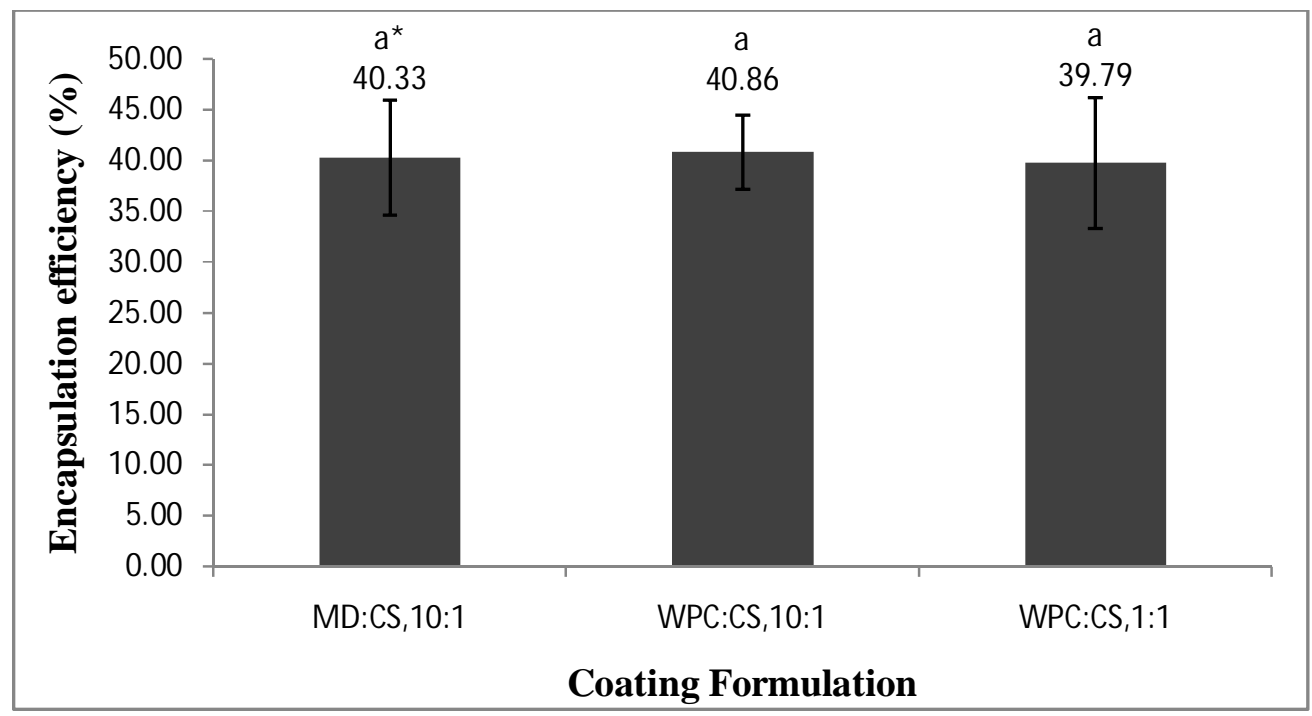

Figure 3.2 Encapsulation efficiencies of microcapsules prepared with WPC:CS at different ratios and MD:CS at a ratio of 10:1.*Different letters represent significant difference $(\mathrm{p} \leq 0.05)$ 
The similar results obtained for both concentrations of WPC:CS could be referred to the results of the studies done by Moschakis et al. (2010). Moschakis et al. (2010) quoted in their studies that 10:1 ratio of WPC:CS formulation was the minimum ratio of emulsifying oil to avoid flocculation. Both studies indicated the effect of flocculation of proteins on emulsion stability. So, there may be an optimum value for the stability of emulsions formed by WPC:CS formulation.

It was observed that $\mathrm{NaCa}$ was a better encapsulating material as compared to GA, CS and WPC since capsules prepared with $\mathrm{NaCa}$ had lower surface oil content indicating higher encapsulation efficiency (Table 3.2). Augustin \& Hemar (2009) and Dickinson (1999) reported that since proteins are amphiphilic compounds, they can interact with hydrophilic and lipophilic compounds which enables the adsorption of the oil droplets and gas bubbles. According to the results of the efficiencies, it was seen that $\mathrm{NaCa}$ was more effective in microencapsulation than WPC. The difference in efficiencies of microcapsules created by NaCa and WPC was consistent with the study by Kagami et al. (2003) reporting the higher surface activity of $\mathrm{NaCa}$ as compared to WPC. The findings of interfacial tension measurements of emulsions in their study indicated the higher emulsification properties of $\mathrm{NaCa}$ over whey protein isolate.

The homogenization techniques affected the encapsulation efficiency significantly. Fig.3.3 showed the efficiency results of microcapsules prepared by MD: $\mathrm{NaCa}$, at a ratio of 1:3 homogenized by US, SC and MF. Microcapsules homogenized with US showed statistically lower encapsulation efficiency than those homogenized with SC and MF (Table B.2) ( $\leq \leq 0.05)$. On the other hand, encapsulation efficiency homogenized with SC and MF were not significantly different from each other (Table B.2) ( $p>0.05)$. The acting forces of high speed in SC generated by the blades led to reach the similar efficiency by MF in which the emulsion was formed by high velocity rates generated from momentum and turbulence in micro channels. Moreau et al., (2003) showed in their study that increasing the speed of the blender decreased the particle size of the emulsions and these values were similar to the results achieved by MF. The decrease in the particle size was related to the increasing stability of emulsions (Jafari et al., 
2006b, 2007) which could explain the increased efficiency of microencapsulation by SC. The encapsulation efficiencies of microcapsules prepared by MF were also higher than US homogenization. This result can also be related to higher emulsion stability achieved by the decreased emulsion particle size by MF homogenization. The results of the higher efficiency found by MF than US can be supported by the results of decreased emulsion size by MF in the study conducted by Mahdi Jafari, He \& Bhandari (2006). The decreased emulsion size by MF over US could also be related to the increased stability of emulsion and accordingly the increase in stability led to production of more efficient microencapsulation.

Table 3.2 Surface oil content (g oil/100 g capsule) and encapsulation efficiency (\%) of microcapsules prepared with different coating formulations

\begin{tabular}{ccc}
\hline $\begin{array}{c}\text { Coating } \\
\text { formulation }\end{array}$ & $\begin{array}{c}\text { Surface Oil Content } \\
\text { (g oil/ 100 g capsule) }\end{array}$ & $\begin{array}{c}\text { Encapsulation efficiency } \\
(\boldsymbol{\%})\end{array}$ \\
\hline MD:GA, 1:3 & $1.57 \pm 0.052$ & $34.30 \pm 0.42$ \\
MD:WPC, $1: 3$ & $1.62 \pm 0.054$ & $38.06 \pm 5.75$ \\
MD:WPC, $1: 4$ & $1.65 \pm 0.087$ & $39.42 \pm 5.20$ \\
\hline MD:CS, 10:1 & $0.92 \pm 0.069$ & $40.33 \pm 8.10$ \\
WPC:CS, 10:1 & $0.89 \pm 0.005$ & $40.86 \pm 5.20$ \\
WPC:CS, $1: 1$ & $1.49 \pm 0.366$ & $39.79 \pm 9.14$ \\
\hline MD:NaCa, $1: 3$ & $0.04 \pm 0.003$ & $56.69 \pm 0.80$ \\
\hline
\end{tabular}




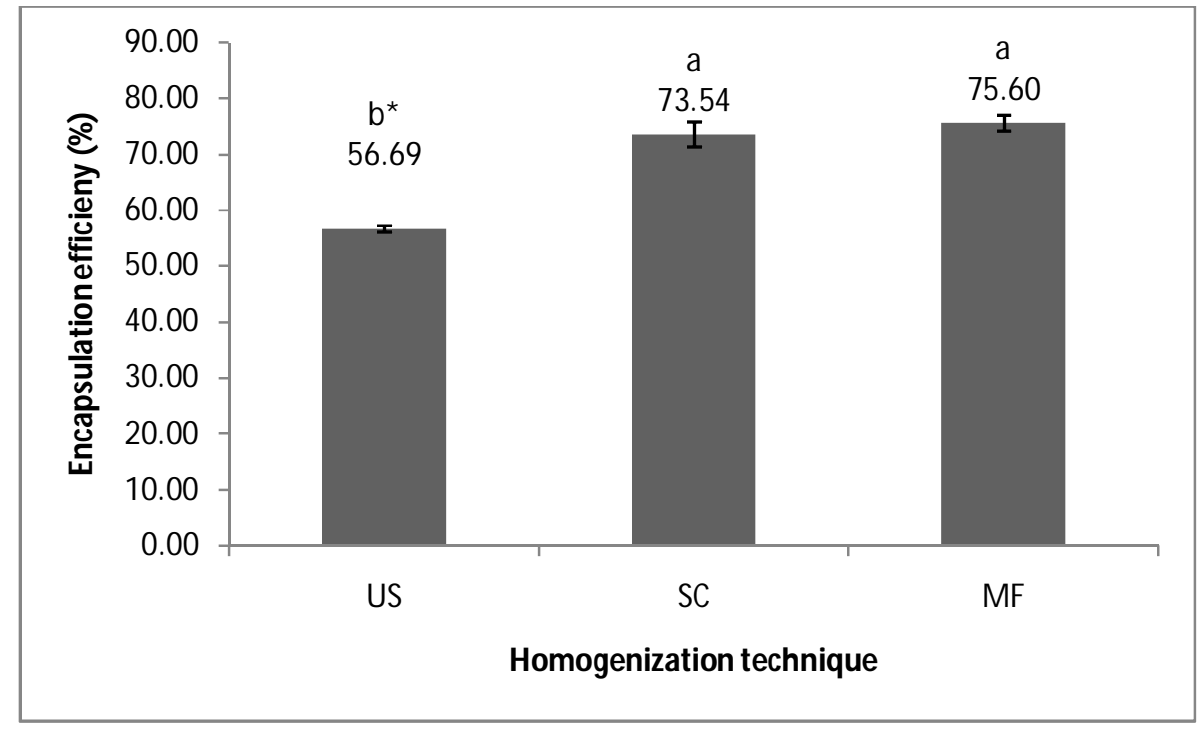

Figure 3.3 Encapsulation efficiencies of microcapsules prepared with MD: $\mathrm{NaCa}$ ratio of 1:3 and homogenized with different techniques (ultrasonication (US), silent crusher (SC) and microfluidization (MF)). *Different letters represent significant difference $(\mathrm{p} \leq 0.05)$

Depending on the results of efficiencies found by application of different homogenization techniques, the effect of different treatment passes in homogenization by MF on microencapsulation efficiency was further analyzed. SC was eliminated due to the reason of small scale production.

In Fig.3.4, the results of the efficiencies found by the treatment of 1, 2 and 3 passes of MF are shown. There were no significant differences between the treatment passes $(\mathrm{p} \leq 0.05)$ (Table B.3). The same effect seen on encapsulation efficiency of each treatment could be explained by the fact that there was the optimum conditions in production of emulsions by microfluidization as stated by Lobo \& Svereika (2003) and Jafari et al. (2006). This situation was expressed as 'over-processing' which was resulted from the increased collision of the emulsion droplets leading to coalescence. The coalescence of the droplets caused unstable 
emulsions and eventually poor microencapsulation efficiencies. The phenomenon of over-processing could explain the efficiency results obtained by different treatment passes.

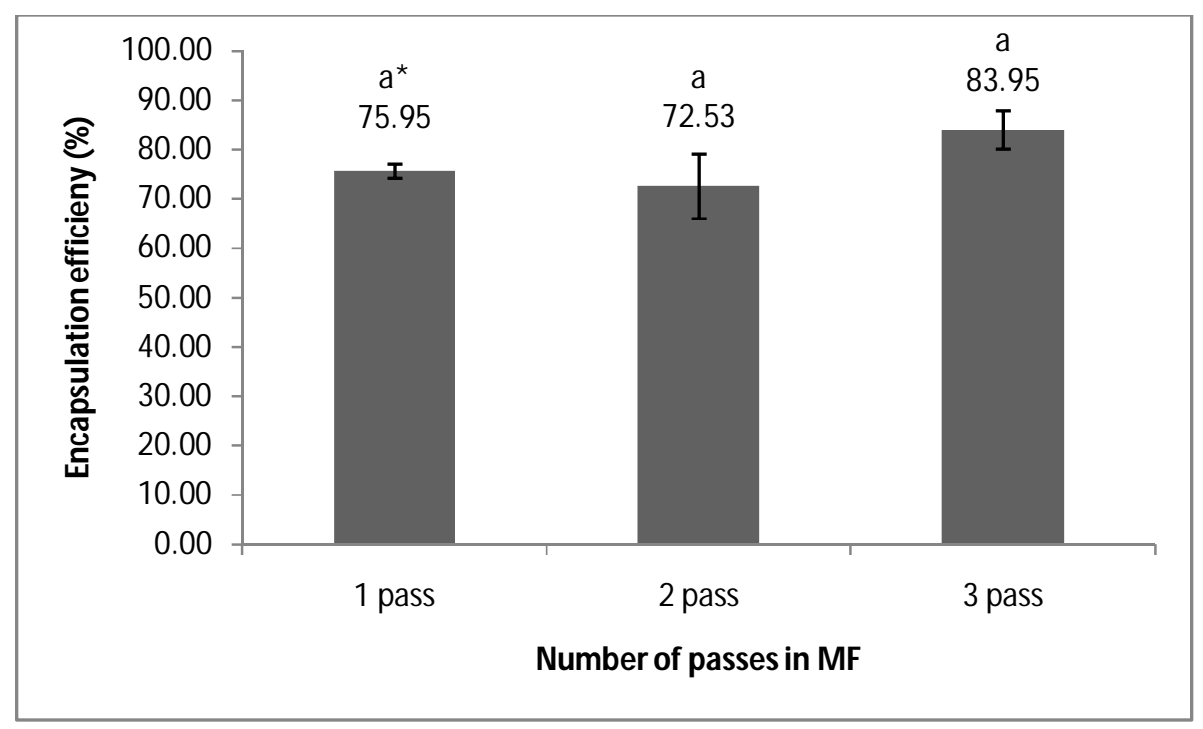

Figure 3.4 Encapsulation efficiencies of microcapsules prepared with $\mathrm{MD}: \mathrm{NaCa}$ ratio of 1:3 and homogenized under different microfluidization treatment passes. *Different letters represent significant difference $(\mathrm{p} \leq 0.05)$

According to the results of the efficiency analyses, formulation of MD: $\mathrm{NaCa}$ at ratio of 1:3, which was the most promising coating material, were chosen for further analyses of particle size and oxidation analyses.

\subsection{Particle Size}

Particle size analyses were carried out for the formulation of MD:NaCa 1:3 homogenized with different homogenization techniques. Table 3.3 represents the 
particle size values of D32 $(\mu \mathrm{m})$ and span of emulsions homogenized with US, SC and MF for 1 pass.

The statistical analyses also showed that there were significant difference between the D32 $(\mu \mathrm{m})$ values of emulsions $(\mathrm{p} \leq 0.05)$ (Table B.4).

Table 3.3 The effect of different homogenization techniques on particle size of emulsions prepared with $\mathrm{MD}: \mathrm{NaCa}$ at a ratio of 1:3: *Different letters represent significant difference $(\mathrm{p} \leq 0.05)$

\begin{tabular}{ccc}
\hline Homogenization technique & D32 $(\boldsymbol{\mu m})$ & Span \\
\hline US & $1.680^{\mathrm{a}}$ & $1.114^{\mathrm{c}}$ \\
SC & $1.480^{\mathrm{b}}$ & $2.082^{\mathrm{b}}$ \\
MF & $0.643^{\mathrm{c}}$ & $4.070^{\mathrm{a}}$ \\
\hline
\end{tabular}

The larger particle size of the emulsions homogenized by US was consistent with the lower efficiency of encapsulation when US was used as compared to MF and SC (Fig. 3.3). It has been shown that MF homogenization was more effective in decreasing the particle sizes than US homogenization in the studies carried out by Mahdi Jafari et al. (2006) and Jafari et al. (2008, 2007). High velocity rates generated by MF in a short time with high energy ceased the disruption of the fluid droplets more effectively than US (Jafari et al., 2006a). The particle size of the emulsion homogenized by MF was also smaller than the particle size of the emulsion homogenized by the SC. This result was similar to the results achieved by Moreau et al. (2003).

Span results showed the reverse trend with D32 values for the particle sizes of the emulsions homogenized by US, SC and MF. The emulsion homogenized by MF with the smallest D32 value had the largest span value and the emulsion by US with the largest D32 value had the smallest span value. This result can also be 
seen in Fig.3.5 as the narrowest curve representing the emulsion of US process and as the widest curve representing the MF process. Jafari et al. (2007) explained the relation of larger particle size and small span value as to be resulted from the formation of uniform droplets in emulsion achieved by US.

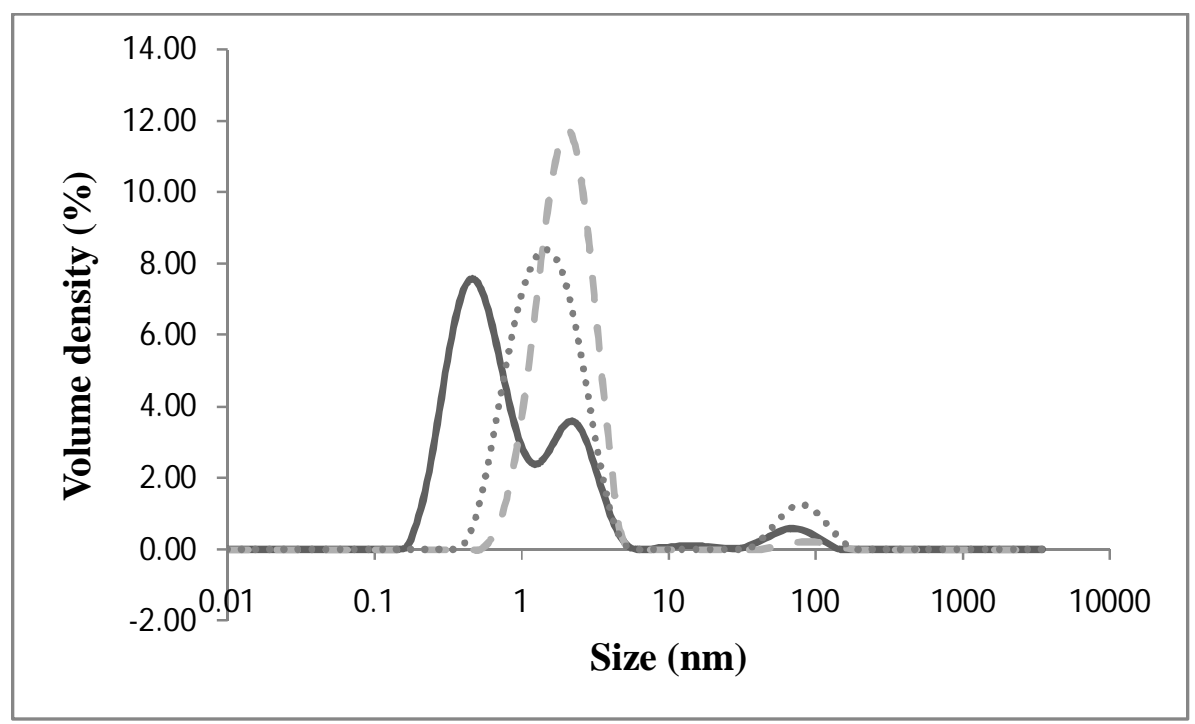

Figure 3.5 Particle size distributions of emulsions prepared with MD:NaCa ratio of 1:3 and homogenized with different techniques (ultrasonication (US)-dashed line, silent crusher (SC)-dotted line and microfluidization (MF)-solid line)

The results of the particle sizes of the emulsions homogenized with different MF treatment passes can be seen in Table.3.4. The results showed that the increase in number of passes decreased the particle sizes of the emulsions. This correlation has also been found by Kuhn \& Cunha (2012) and Jafari et al. (2006). The same trend was also seen in span values. As the number of cycles in homogenization increased, the span values decreased. This phenomenon was also consistent with the findings by Kuhn \& Cunha (2012) and Jafari et al. (2006). As can be seen in Fig.3.6, the span results are well matched with the curves for 1, 2 and 3 pass. The widest curve represented 1 pass which had the largest span value and the 
narrowest represented the 3 pass which had the smallest span value. It has been well noted by Kuhn \& Cunha (2012) and Jafari et al. (2006) that the increased number of cycles were effective in creating emulsions with smaller particle size as disrupting the droplets repeatedly and eventually preventing the coalescence.

Table 3.4 Particle size analyses of emulsions prepared with $\mathrm{MD}: \mathrm{NaCa}$ at a ratio of 1:3 and homogenized with different microfluidization treatment passes: $*$ Different letters represent significant difference $(\mathrm{p} \leq 0.05)$

\begin{tabular}{ccc}
\hline Number of pass & D32 $(\boldsymbol{\mu m})$ & Span \\
\hline 1 pass & $0.643^{\mathrm{a}}$ & $4.070^{\mathrm{a}}$ \\
2 pass & $0.316^{\mathrm{b}}$ & $0.842^{\mathrm{b}}$ \\
3 pass & $0.278^{\mathrm{c}}$ & $0.746^{\mathrm{b}}$ \\
\hline
\end{tabular}




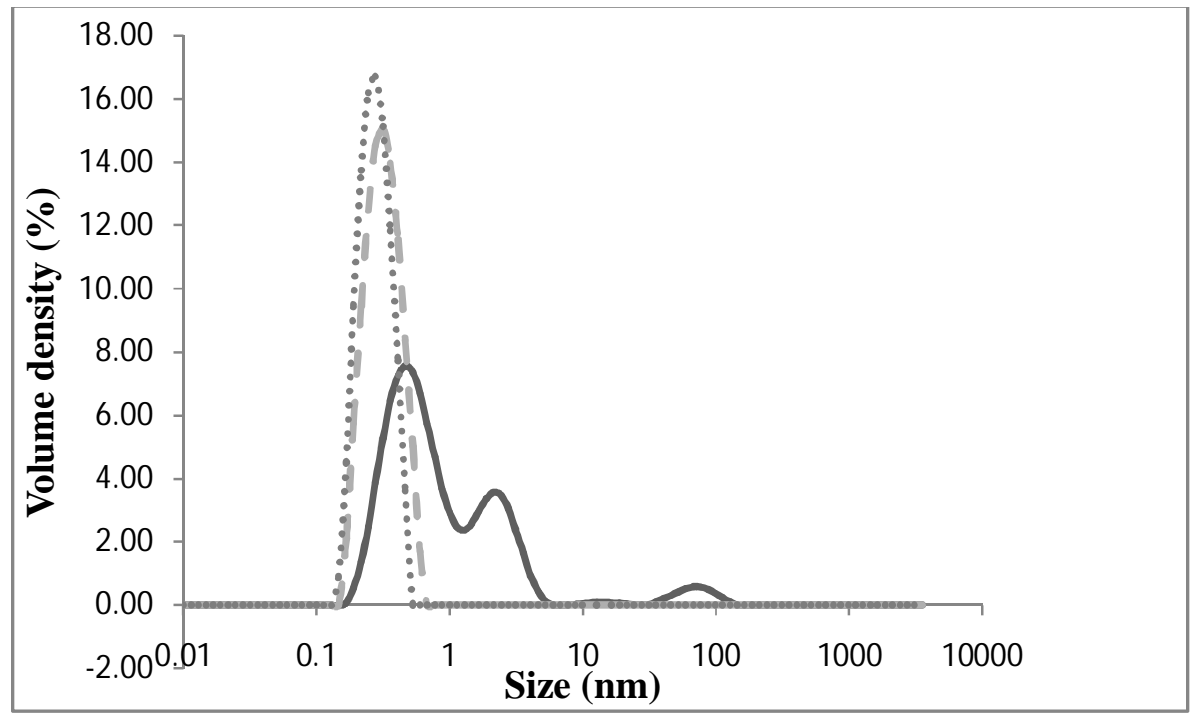

Figure 3.6 Particle size distributions of emulsions prepared with MD:NaCa ratio of 1:3 and homogenized with different microfluidization treatment passes (1 pass: solid line, 2 pass: dashed line, 3 pass: dotted line)

As the number of passes increased, the particle size of the emulsions decreased; however the efficiency of the emulsions were statistically not different. Therefore, for the storage stability analyses microcapsules prepared with 1 pass treatment of MF was selected for storage stability analysis.

\subsection{Storage Stability of Capsules}

Oxidation analyses were performed to determine the effects of encapsulation on storage stability. Oxidative stability is the significant criteria for microencapsulation of oils in order to determine the ability of wall material in protecting the oil from oxidation. Therefore, storage stability analysis was carried out for microcapsules prepared with $\mathrm{MD}: \mathrm{NaCa}$ at a ratio of 1:3 processed under 
MF with 1 pass, which had the highest encapsulation efficiency and compared with the non-encapsulated. In order to evaluate the storage stability of microcapsules, accelerated storage stability test was performed at $45^{\circ} \mathrm{C}$ compared with $15^{\circ} \mathrm{C}$ storage for both totox values and $\alpha$-tocopherol concentration. The microcapsules and fresh oils were stored at $15^{\circ} \mathrm{C}$ for 40 days and at $45^{\circ} \mathrm{C}$ for 28 days at $33.3 \pm 0.1 \%$ and $31.10 \pm 0.1 \mathrm{RH}$ environments, respectively.

In Fig.3.7, totox values of encapsulated and fresh oil during storage at $15^{\circ} \mathrm{C}$ and $45^{\circ} \mathrm{C}$ were given. According to the results, it can be seen that the totox values of the sample increased as the exposure to oxygen and temperature, which are most effective oxidative stresses, increased. The rate of increase in totox values of fresh oil was apparently higher than the totox values of microcapsules. This could be explained by the fact that the wall structure of microencapsulation surrounding the core material protected the material from oxidation. $\mathrm{NaCa}$ is well known for its good barrier forming ability providing a protective coat against oxidation (Singh, 2011). The protective effect of the coating to retard the oil oxidation could be obviously seen in the first 7 days for both $15^{\circ} \mathrm{C}$ and $45^{\circ} \mathrm{C}$ storage temperatures. Similar results were obtained in the studies conducted by Kagami et al. (2003) and Karaca, Low, \& Nickerson (2013). 


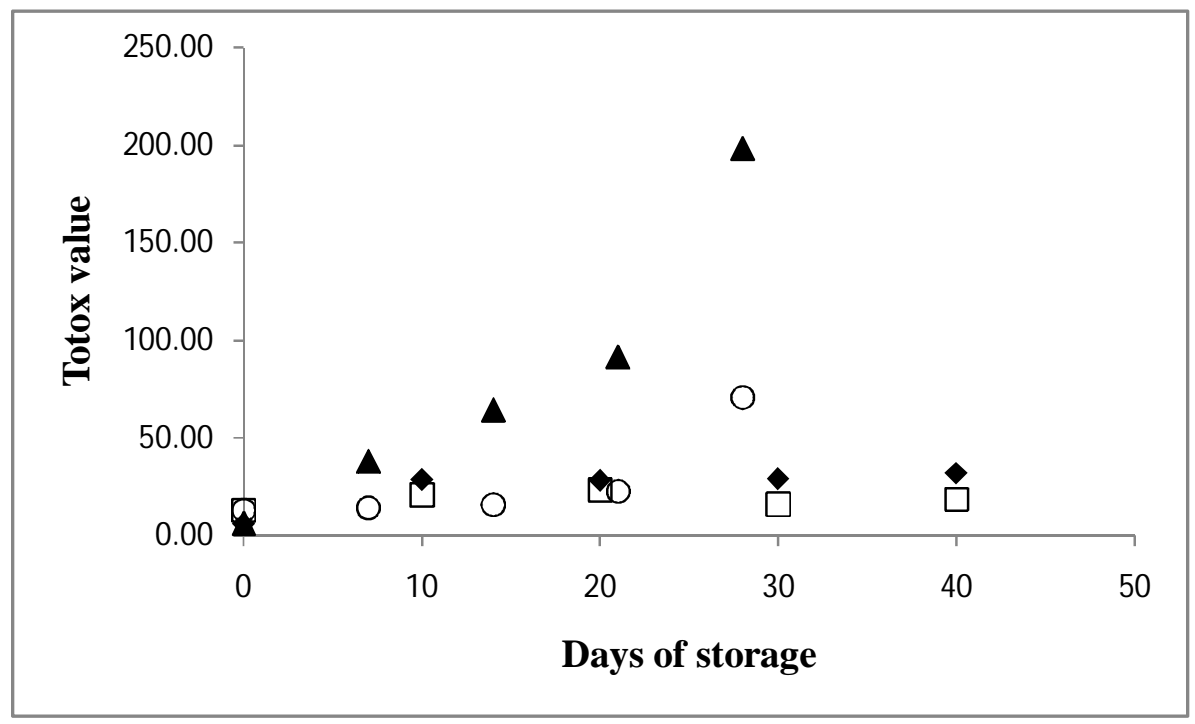

Figure 3.7 Totox values of fresh oil and microcapsules prepared with $\mathrm{MD}: \mathrm{NaCa}$ ratio of $1: 3$ and stored at $15^{\circ} \mathrm{C}$ for 40 days and $45^{\circ} \mathrm{C}$ for 28 days at $33 \% \mathrm{RH}$ ( : fresh oil at $15^{\circ} \mathrm{C}, \square$ : microcapsule at $15^{\circ} \mathrm{C}, \boldsymbol{\Delta}$ : fresh oil at $45^{\circ} \mathrm{C}, \circ$ : microcapsule at $45^{\circ} \mathrm{C}$ )

When the results of fresh oils and microcapsules were compared, it was seen that microencapsulation was efficient in protecting the oil from oxidation during storage. The totox values of microcapsules stored at both $15^{\circ} \mathrm{C}$ and $45^{\circ} \mathrm{C}$ were higher than fresh oil on day 0 as reported in the study conducted by Karaca et al. (2013), which could have resulted from processing during microencapsulation. On day 0 , the totox values of fresh oil and microcapsules were found as 6.15 and 13.15 respectively. Totox values of microcapsules stored at both $15^{\circ} \mathrm{C}$ and $45^{\circ} \mathrm{C}$ were nearly the same and constant at the end of 20 days. After 20 days, there was a sharp increase in the totox values microcapsules stored at $45^{\circ} \mathrm{C}$. The reason of the decrease in oxidative stability of microcapsules could be the increase in permeability of wall material. Hardas, Danviriyakul, Foley, Nawar, \& Chinachoti (2000) and Partanen et al. (2002) reported in their studies that increase in 
temperature led to increase in permeability due to the change in glass transition temperature and decrease the stability of the structure. Eventually, as the oxygen and light exposure of oil increased the oil oxidation increased.

Fig.3.8 represented the change in a-tocopherol concentration of fresh oil and microcapsules prepared with $\mathrm{MD}: \mathrm{NaCa}$ ratio of $1: 3$ and stored at $15^{\circ} \mathrm{C}$ during 24 days and at $45^{\circ} \mathrm{C}$ during 21 days. It was obviously seen that the concentration of $\alpha$-tocopherol in fresh oil was much higher than that in microcapsules on day $0 . \alpha$ tocopherol was known to be susceptible to oxygen and temperature, which has been reported in several studies such as Bruscatto et al. (2009), Rastrelli et al. (2002) and Capitani et al. (2011). Thus, the processing conditions exposing to oxygen and temperature could cause the degradation. On the other side, the degradation of $\alpha$-tocopherol in fresh oil was found to be faster than that in microcapsules, which clearly showed the protective effect of microencapsulation on degradation of $\alpha$-tocopherol. The degradation of $\alpha$-tocopherol in microcapsules stored at both temperatures of $15^{\circ} \mathrm{C}$ and $45^{\circ} \mathrm{C}$ were nearly the same, which could indicate the stability of wall material at $45^{\circ} \mathrm{C}$ within 20 days. When the oxidative stability results were considered, the increase in totox value was seen after 20 days storage of microcapsules. 


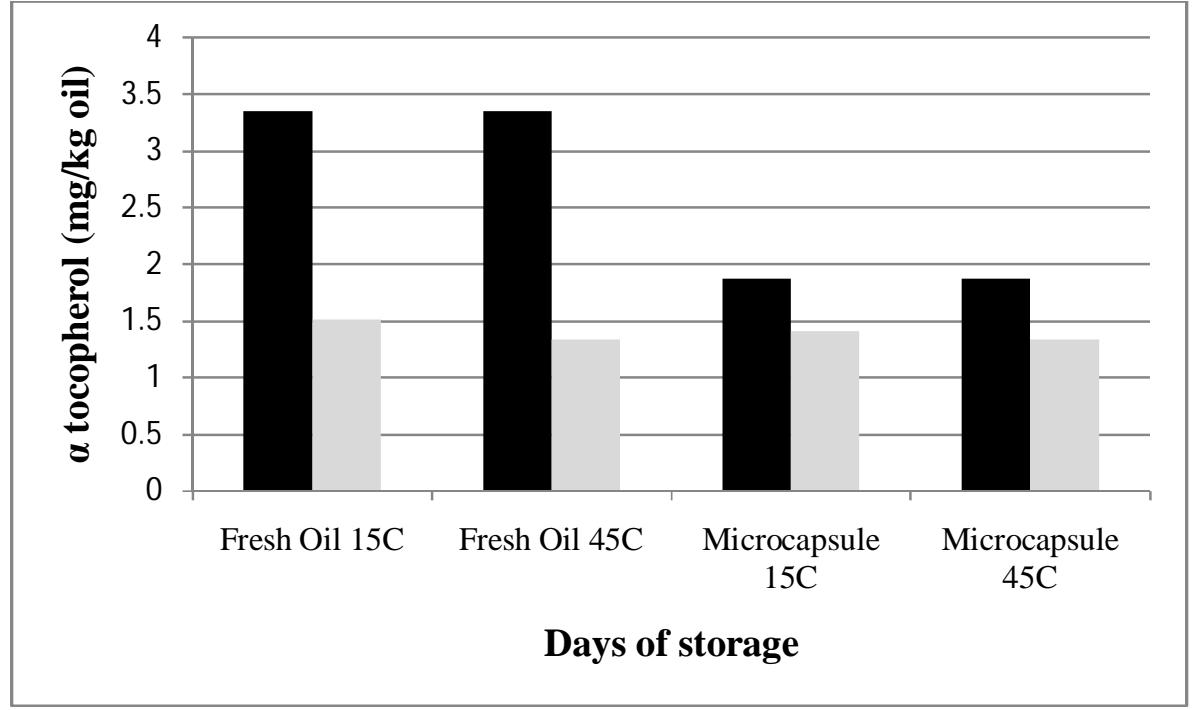

Figure 3.8 $\alpha$-tocopherol concentration of fresh oil and microcapsules prepared with MD:NaCa ratio of 1:3 and stored at 33\% RH ( $\square$ : 0 day, $\square$ : end of storage for $\alpha$ tocopherol analysis which is 24 days at $15^{\circ} \mathrm{C}$ and 21 days at $45^{\circ} \mathrm{C}$ ) 


\section{CONCLUSION AND RECOMMENDATIONS}

In order to determine the optimum conditions for encapsulation of wheat germ oil, encapsulation efficiency, particle size distribution and storage stability analyses including the determination of totox values and $\alpha$-tocopherol concentration were carried out.

Encapsulation efficiency of microcapsules coated with MD: $\mathrm{NaCa}$ at concentration of 1:3 was found to be the highest among other coating materials used in this study. Encapsulation efficiency of microcapsules was different when different homogenization techniques were used. MF and SC were found to be much more effective in the formation of microcapsules at higher efficiencies. Increasing the number of passes of MF did not affect the efficiency of microcapsules.

When MD: $\mathrm{NaCa}$ at a ratio of 1:3 was used as a coating material in emulsion preparation, it was observed that the change in homogenization technique affected the particle size of emulsions significantly. US homogenization created the largest particle size and MF homogenization created the smallest particle size. As the number of passes in MF homogenization increased, the particle size of emulsions decreased.

In the storage stability analyses, totox values and $\alpha$-tocopherol concentration of microcapsules were determined. Encapsulation was found to be effective in retarding oxidation of wheat germ oil during storage at $45^{\circ} \mathrm{C}$. Although, the storage analyses showed promising effect of microencapsulation, encapsulation with MD:NaCa combination was not sufficient in retarding the degradation of the core material after 20 days.

For future study, the effect of different concentrations of $\mathrm{NaCa}$ on the microencapsulation efficiency could be investigated. In order to enhance the efficiency, double emulsion would be studied as promising technique for encapsulation of wheat germ oil. 


\section{REFERENCES}

Aghbashlo, M., Mobli, H., Madadlou, A., \& Rafiee, S. (2012). The correlation of wall material composition with flow characteristics and encapsulation behavior of fish oil emulsion. Food Research International, 49(1), 379-388.

Akhtar, M., \& Dickinson, E. (2007). Whey protein-maltodextrin conjugates as emulsifying agents: An alternative to gum arabic. Food Hydrocolloids, 21(4), 607-616.

AOCS. (1998a). Official method Cd 18-90, p-Anisidine value. In Official Methods and Recommended Practices of the American Oil Chemists' Society (5th ed.). AOCS, Campaign, III.

AOCS. (1998b). Official method Cd 8-53, Peroxide value. In Official Methods and Recommended Practices of the American Oil Chemists' Society (5th ed., pp. 2-5). AOCS, Campaign, III.

Augustin, M. A., \& Hemar, Y. (2009). Nano- and micro-structured assemblies for encapsulation of food ingredients. Chemical Society Reviews, 38(4), 902-12.

Ayorinde, F. O., Eribo, B. E., Balan, K. V., Johnson, J. H., \& Wan, L. W. (1999). Determination of major triacylglycerol components of polyunsaturated specialty oils using matrix-assisted laser desorption/ ionization time-of-flight mass spectrometry. Rapid Communications in Mass Spectrometry, 13(10), 937-942.

Bruscatto, M. H., Zambiazi, R. C., Sganzerla, M., Pestana, V. R., Otero, D., Lima, R., \& Paiva, F. (2009). Degradation of Tocopherols in Rice Bran Oil Submitted to Heating at Different Temperatures, Journal of Chromatographic Science, 47(October), 762-765.

Bruzzese, E., Volpicelli, M., Squeglia, V., Bruzzese, D., Salvini, F., Bisceglia, M., Lionetti, P., Cinquetti , M., Iacono, G., Amarri, S. \& Guarino, A. (2009). A formula containing galacto- and fructo-oligosaccharides prevents intestinal and extra-intestinal infections: an observational study. Clinical Nutrition (Edinburgh, Scotland), 28(2), 156-61.

Bushuk, W., \& Rasper, V. F. (1994). Wheat: Production, Properties and Quality. UK, Chapman \& Hall. 
Calvo, P., Castaño, A. L., Lozano, M., \& González-Gómez, D. (2012). Microencapsulation of refined olive oil: influence of capsule wall components and the addition of antioxidant additives on the shelf life and chemical alteration. Journal of the Science of Food and Agriculture, 92(13), 2689-95.

Calvo, P., Hernández, T., Lozano, M., \& González-Gómez, D. (2010). Microencapsulation of extra-virgin olive oil by spray-drying: Influence of wall material and olive quality. European Journal of Lipid Science and Technology, 112(8), 852-858.

Capitani, M., Mateo, C. M., \& Nolasco, S. M. (2011). Effect of Temperature and Storage Time of Wheat Germ on the Oil Tocopherol Concentration. Brazilian Journal of Chemical Engineering, 28(02), 243-250.

Chew, N. Y. K., \& Chan, H. K. (2006). Effect of Powder Polydispersity on Aerosol Generation, Journal of Pharmacy and Pharmaceutical Science, 5(2), $162-168$.

Cucheval, A., \& Chow, R. C. Y. (2008). A study on the emulsification of oil by power ultrasound. Ultrasonics Sonochemistry, 15(5), 916-20.

Desrumaux, A., \& Marcand, J. (2002). Formation of sunflower oil emulsions stabilized by whey proteins with high-pressure homogenization (up to 350 $\mathrm{MPa}$ ): effect of pressure on emulsion characteristics, International Journal of Food Science and Technology, 37, 263-269.

Dickinson, E. (1999). Adsorbed protein layers at fluid interfaces: interactions, structure and surface rheology. Colloids and Surfaces B: Biointerfaces, 15(2), 161-176.

Dickinson, E. (2001). Milk protein interfacial layers and the relationship to emulsion stability and rheology. Colloids and Surfaces B: Biointerfaces, 20(3), 197-210.

Dubois, J. (1995). Determination of peroxide value and anisidine value using Fourier Transform Infrared Spectroscopy. McGilll University, Ottawa.

Dunford, N. T. (2012). Food and Industrial Bioproducts and Bioprocessing. John Wiley \& Sons.

Dzondo-Gadet, M., Nzikou, J. M., Etoumongo, A., Linder, M., \& Desobry, S. (2005). Encapsulation and storage of safou pulp oil in 6DE maltodextrins. Process Biochemistry, 40(1), 265-271. 
Eisenmenger, M., \& Dunford, N. T. (2007). Bioactive Components of Commercial and Supercritical Carbon Dioxide Processed Wheat Germ Oil. Journal of the American Oil Chemists' Society, 85(1), 55-61.

Eisenmenger, M. J. (2003). Supercritical Fluid Extraction, Fractionation, and Characterization of Wheat Germ Oil. Oklahoma State University, Oklahoma.

FAO. (2013). Crop Prospects and Food Situation, FAO. Retrieved on November 25, 2014 from http://www.fao.org/docrep/018/aq114e/aq114e00.htm.

FAO. (2014). FAO Cereal Supply and Demand Brief, FAO, Food and Agriculture Organization of the United Nations. Retrieved on November 25, 2014, from http://www.fao.org/worldfoodsituation/csdb/en/

Faustman, C., Cassens, R. G., Schaefer, D. M., Buege, D. R., Williams, S. N., \& Scheller, K. K. (1989). Improvement of Pigment and Lipid Stability in Holstein Steer Beef by Dietary Supplementation with Vitamin E. Journal of Food Science, 54(4), 858-862.

Gaikwad, S. G., \& Pandit, A. B. (2008). Ultrasound emulsification: effect of ultrasonic and physicochemical properties on dispersed phase volume and droplet size. Ultrasonics Sonochemistry, 15(4), 554-63.

Gallardo, G., Guida, L., Martinez, V., López, M. C., Bernhardt, D., Blasco, R., Pedroza-Islas, R. \& Hermida, L. G. (2013). Microencapsulation of linseed oil by spray drying for functional food application. Food Research International, 52(2), 473-482.

Garti, N., \& McClements, D. J. (2012). Encapsulation Technologies and Delivery Systems for Food Ingredients and Nutraceuticals. UK, Woodhead Publishing Limited.

Gouin, S. (2004). Microencapsulation: industrial appraisal of existing technologies and trends. Trends in Food Science \& Technology, 15(7-8), 330-347.

Greenspan, L. (1977). Humidity fixed points of binary saturated aqueous solutions. Journal of Research of the National Bureau of Standards-A. Physics and Chemistry, 81(1), 89-96.

Güntensperger, B., Hämmerli-Meier, D. E., \& Escher, F. E. (2006). Rosemary Extract and Precooking Effects on Lipid Oxidation in Heat-Sterilized Meat. Journal of Food Science, 63(6), 955-957. 
Halliwell, B. (1993). Lipid peroxidation: its mechanism, measurement, and significance. The American Journal of Clinical Nutrition, 1993:57(suppl):715S-25S.

Hamaker, B. R. (2007). Technology of Functional Cereal Products (Vol. 8). Cambridge, Woodhead Publishing Limited.

Han, L., Li, L., Li, B., Zhao, L., Liu, G., Liu, X., \& Wang, X. (2014). Effect of high pressure microfluidization on the crystallization behavior of palm stearin - palm olein blends. Molecules, 19(4), 5348-59.

Hardas, N., Danviriyakul, S., Foley, J. L., Nawar, W. W., \& Chinachoti, P. (2000). Accelerated Stability Studies of Microencapsulated Anhydrous Milk Fat. LWT - Food Science and Technology, 33(7), 506-513.

Heinzelmann, K., \& Franke, K. (1999). Using freezing and drying techniques of emulsions for the microencapsulation of fish oil to improve oxidation stability. Colloids and Surfaces B: Biointerfaces, 12(3-6), 223-229.

Heinzelmann, K., \& Franke, K. (2000). Protection of fish oil from oxidation by microencapsulation using freeze-drying, European Journal of Lipid Science and Technology, 102(2), 114-121.

Heinzelmann, K., Franke, K., Velasco, J., \& Márquez-Ruiz, G. (2000). Microencapsulation of fish oil by freeze-drying techniques and influence of process parameters on oxidative stability during storage. European Food Research and Technology, 211(4), 234-239.

Hogan, S. A, McNamee, B. F., O'Riordan, E. D., \& O'Sullivan, M. (2001a). Emulsification and microencapsulation properties of sodium caseinate/carbohydrate blends. International Dairy Journal, 11(3), 137-144.

Hogan, S. A., McNamee, B. F., O’Riordan, E. D., \& O’Sullivan, M. (2001b). Microencapsulating Properties of Sodium Caseinate. Journal of Agricultural and Food Chemistry, 49(4), 1934-1938.

Hornero-Méndez, D., Pérez-Gálvez, A., \& Mínguez-Mosquera, M. I. (2001). A rapid spectrophotometric method for the determination of peroxide value in food lipids with high carotenoid content. Journal of the American Oil Chemists' Society, 78(11), 1151-1155.

Huang, F., Ju, Y., \& Huang, C. (1997). Enrichment of $\gamma$-Linolenic Acid from Borage Oil via Lipase-Catalyzed Reactions, Journal of American Oil Chemists' Society, 74(8). 
Irmak, S., Dunford, N. T., \& Milligan, J. (2006). Policosanol contents of beeswax, sugar cane and wheat extracts. Food Chemistry, 95(2), 312-318.

Jafari, S. M., Assadpoor, E., Bhandari, B., \& He, Y. (2008). Nano-particle encapsulation of fish oil by spray drying. Food Research International, 41(2), 172-183.

Jafari, S. M., He, Y., \& Bhandari, B. (2006a). Nano-Emulsion Production by Sonication and Microfluidization-A Comparison. International Journal of Food Properties, 9(3), 475-485.

Jafari, S. M., He, Y., \& Bhandari, B. (2006b). Optimization of nano-emulsions production by microfluidization. European Food Research and Technology, 225(5-6), 733-741.

Jafari, S. M., He, Y., \& Bhandari, B. (2007). Production of sub-micron emulsions by ultrasound and microfluidization techniques. Journal of Food Engineering, 82(4), 478-488.

Jayasundera, M., Adhikari, B., Aldred, P., \& Ghandi, A. (2009). Surface modification of spray dried food and emulsion powders with surface-active proteins: A review. Journal of Food Engineering, 93(3), 266-277.

Kagami, Y., Sugimura, S., Fujishima, N., Matsuda, K., Kometani, T., \& Matsumura, Y. (2003). Oxidative Stability, Structure, and Physical Characteristics of Microcapsules Formed by Spray Drying of Fish Oil with Protein and Dextrin Wall Materials, JFS: Food Engineering and Physical Properties 68(7), 2248-2255.

Karaca, A. C., Low, N., \& Nickerson, M. (2013). Encapsulation of flaxseed oil using a benchtop spray dryer for legume protein-maltodextrin microcapsule preparation. Journal of Agricultural and Food Chemistry, 61(21), 5148-55.

Kentish, S., Wooster, T. J., Ashokkumar, M., Balachandran, S., Mawson, R., \& Simons, L. (2008). The use of ultrasonics for nanoemulsion preparation. Innovative Food Science \& Emerging Technologies, 9(2), 170-175.

Khan, K., \& Shewry, P. R. (2009). Wheat: Chemistry and Technology (4th ed.). St Paul, Minnesota: AACC International Publisher.

Kingston, E. R., Monahan, F. J., Buckley, D. J., \& Lynch, P. B. (1998). Lipid Oxidation in Cooked Pork as Affected by Vitamin E, Cooking and Storage Conditions. Journal of Food Science, 63(3), 386-389. 
Klaypradit, W., \& Huang, Y. W. (2008). Fish oil encapsulation with chitosan using ultrasonic atomizer. LWT - Food Science and Technology, 41(6), $1133-1139$.

Klinkesorn, U., Sophanodora, Pariat S., Chinachoti, P. C., McClements, D. J., \& Ecker, E. A. (2005). Stability of Spray-Dried Tuna Oil Emulsions Encapsulated with Two-Layered Interfacial Membranes. Journal of Agricultural and Food Chemistry, 53(21) 8365-8371.

Klinkesorn, U., Sophanodora, P., Chinachoti, P., Decker, E. \& McClements, D. J. (2006). Characterization of spray-dried tuna oil emulsified in two-layered interfacial membranes prepared using electrostatic layer-by-layer deposition. Food Research International, 39(4), 449-457.

Koeber, R., Buchgraber, M., Ulberth, F., Bernreuther, A., Schimmel, H., Anklam, E., \& Pauwels, J. (2003). The Certification of the Content of Five Triglycerides in Cocoa Butter. European Commission, Directorate-General Joint Research Center, Institute of Reference Materials and Measurements, Report EUR 20781, Luxembourg.

Kuhlmann, W. D. (2006). Buffer solutions. 69120 Heidelberg, Germany: Division of Radiooncology, Deutsches Krebsforschungszentrum.

Kuhn, K. R., \& Cunha, R. L. (2012). Flaxseed oil - Whey protein isolate emulsions: Effect of high pressure homogenization. Journal of Food Engineering, 111(2), 449-457.

Kumar, P., Yadava, R., Gollen, B., Kumar, S., Verma, R. K., \& Yadav, S. (2011). Nutritional contents and medicinal properties of wheat: A review. Life Sciences and Medicine Research, 2011, 1-10.

Length, F. (2006). Chemical composition and insecticidal properties of the underutilized Jatropha curcas seed oil, African Journal of Biotechnology, 5(10), 901-906.

Leong, T. S. H., Wooster, T. J., Kentish, S. E., \& Ashokkumar, M. (2009). Minimising oil droplet size using ultrasonic emulsification. Ultrasonics Sonochemistry, 16(6), 721-7.

Li, Y., Ai, L., Yokoyama, W., Shoemaker, C. F., Wei, D., Ma, J., \& Zhong, F. (2013). Properties of chitosan-microencapsulated orange oil prepared by spray-drying and its stability to detergents. Journal of Agricultural and Food Chemistry, 61(13), 3311-9. 
Lin, C. F., Gray, J. I., Asghar, A., Buckley, D. J., Booren, A. M., \& Flegal, C. J. (1989). Effects of Dietary Oils and alpha-Tocopherol Supplementation on Lipid Composition and Stability of Broiler Meat. Journal of Food Science, 54(6), 1457-1460.

Lobo, L., \& Svereika, A. (2003). Coalescence during emulsification. 2. Role of small molecule surfactants. Journal of Colloid and Interface Science, 261(2), 498-507.

Mann, G. V. (1977). A factor in yogurt which lowers cholesteremia in man. Atherosclerosis. Elsevier, 26(3), 335-340.

Marinova, E. M., Seizova, K. A., Totseva, I. R., Panayotova, S. S., Marekov, I. N., \& Momchilova, M. (2012). Oxidative changes in some vegetable oils during heating at frying temperature, Bulgarian Chemical Communications, 44(1), 57-63.

McClements, D. J. (2004). Food Emulsions: Principles, Practices, and Techniques, Second Edition. NW, CRC Press.

Megahad, O. A., \& El Kinawy, O. S. (2007). Studies on the extraction of wheat germ oil by commercial hexane. Fats and Oils Department, NRC, Cairo, Egypt, 53(4), 414-418.

Megahed, M. (2011). Study on stability of wheat germ oil and lipase activity of wheat germ during periodical storage. Agriculture and Biology Journal of North America, 2(1), 163-168.

Mielnik, M. B., Olsen, E., Vogt, G., Adeline, D., \& Skrede, G. (2006). Grape seed extract as antioxidant in cooked, cold stored turkey meat. LWT - Food Science and Technology, 39(3), 191-198.

Millqvist-Fureby, A. (2003). Characterisation of spray-dried emulsions with mixed fat phases. Colloids and Surfaces B: Biointerfaces, 31(1-4), 65-79.

G mez, A. M., \& Mart nez de la Ossa, E. (2000). Quality of wheat germ oil extracted by liquid and supercritical carbon dioxide. Journal of American Oil Chemists' Society, 77(9), 969-974.

Moreau, L., Kim, H. J., Decker, E. A., \& McClements, D. J. (2003). Production and Characterization of Oil-in-Water Emulsions Containing Droplets Stabilized by -Lactoglobulin - Pectin Membranes, Journal of Agrucultural Food and Chemistry, 51, 6612-6617. 
Moschakis, T., Murray, B. S., \& Biliaderis, C. G. (2010). Modifications in stability and structure of whey protein-coated $\mathrm{o} / \mathrm{w}$ emulsions by interacting chitosan and gum arabic mixed dispersions. Food Hydrocolloids, 24(1), 817.

Naz, S., Sheikh, H., Siddiqi, R., \& Sayeed, S. A. (2004). Oxidative stability of olive, corn and soybean oil under different conditions. Food Chemistry, $88(2), 253-259$.

Niki, E., Yoshida, Y., Saito, Y., \& Noguchi, N. (2005). Lipid peroxidation: mechanisms, inhibition, and biological effects. Biochemical and Biophysical Research Communications, 338(1), 668-76.

Özalp Özen, B., Eren, M., Pala, A., Özmen, İ., \& Soyer, A. (2011). Effect of plant extracts on lipid oxidation during frozen storage of minced fish muscle. International Journal of Food Science \& Technology, 46(4), 724-731.

Özcan, M. M., Rosa, A., Dessı, M. A., Marongıu, B., Pıras, A., \& Al-juhaimi, F. Y. I. (2013). Quality of Wheat Germ Oil Obtained by Cold Pressing and Supercritical Carbon Dioxide Extraction, Czech Journal of Food Science, 31(3), 236-240.

Partanen, R., Yoshii, H., Kallio, H., Yang, B., \& Forssell, P. (2002). Encapsulation of Sea Buckthorn Kernel Oil, Journal of American Oil Chemists' Society, 79(3), 219-223.

Player, M. E., Kim, H. J., Lee, H. O., \& Min, D. B. (2006). Stability of alpha-, gama-, or delta-Tocopherol during Soybean Oil Oxidation. Journal of Food Science, 71(8), C456-C460.

Pomeranz, Y. (1987). Modern cereal science and technology. New York: VCH Publishers.

Rahman, M. S. (2007). Handbook of Food Preservation, Second Edition. NW, CRC Press.

Rastrelli, L., Passi, S., Ippolito, F., Vacca, G., \& De Simone, F. (2002). Rate of Degradation of $r$-Tocopherol, Squalene, Phenolics, and Polyunsaturated Fatty Acids in Olive Oil during Different Storage Conditions, Journal of Agrucultural Food and Chemistry, 50, 5566-5570.

Repetto, M., Semprine J. \& Boveris, A. (2012). Lipid Peroxidation: Chemical Mechanism, Biological Implications and Analytical Determination, Lipid Peroxidation, Dr. Angel Catala, ISBN: 978-953-51-0716-3, InTech, DOI: $10.5772 / 45943$. 
Risch, S. J., \& Reineccius, G. A. (1995). Encapsulation and Controlled Release of Food Ingredients, Volume 590. Washington, DC, American Chemical Society.

Saarela, M. (2011). Functional Foods: Concept to Product, Second Edition. UK, Woodhead Publishing.

Sagalowicz, L., \& Leser, M. E. (2010). Delivery systems for liquid food products. Current Opinion in Colloid \& Interface Science, 15(1-2), 61-72.

Schofield, J. D. (2000). Wheat Structure, Biochemistry and Functionality. Royal Society of Chemistry. UK, MPG Books Ltd.

Semb, T. N. (2012). Analytical Methods for Determination of the Oxidative Status in Oils. Norwegian University of Scince and Technology, Department of Biotechnology. Retrieved on November 25, 2014 from http://ntnu.divaportal.org/smash/get/diva2:536470/FULLTEXT01.pdf.

Sen Gupta, S., Ghosh, S., Maiti, P., \& Ghosh, M. (2012). Microencapsulation of conjugated linolenic acid-rich pomegranate seed oil by an emulsion method. Food Science and Technology International = Ciencia Y Tecnología de Los Alimentos Internacional, 18(6), 549-58.

Shibamoto, T., Kazuki, K., Fereidoon, S., \& Chi-Tang, H. (2008). Functional Food and Health. Washington, DC , American Chemical Society.

Silva, K. A., Coelho, M. A. Z., Calado, V. M. A., \& Rocha-Leão, Maria, H. M. (2013). Olive oil and lemon salad dressing microencapsulated by freezedrying. LWT - Food Science and Technology, 50(2), 569-574.

Singh, H. (2011). Aspects of milk-protein-stabilised emulsions. Food Hydrocolloids, 25(8), 1938-1944.

Sonvico, F., Cagnani, A., Rossi, A, Motta, S., Di Bari, M. T., Cavatorta, F., Alonso, M. J., Deriu, A., \& Colombo, P. (2006). Formation of self-organized nanoparticles by lecithin/chitosan ionic interaction. International Journal of Pharmaceutics, 324(1), 67-73.

Soyer, A., Özalp, B., Dalmış, Ü., \& Bilgin, V. (2010). Effects of freezing temperature and duration of frozen storage on lipid and protein oxidation in chicken meat. Food Chemistry, 120(4), 1025-1030. 
Stewart, R. R. C., \& Bewley, J. D. (1980). Lipid Peroxidation Associated with Accelerated Aging of Soybean Axes. Plant Physiology, 65(2), 245-248.

Tokuşoğlu, Ö. (2011). Fruit and Cereal Bioactives: Sources, Chemistry, and Applications. New York: CRC Press.

Turasan, H. (2014). Encapsulation of Rosemary Essential Oil.

Vega, C., \& Roos, Y. H. (2006). Invited review: spray-dried dairy and dairy-like emulsions--compositional considerations. Journal of Dairy Science, 89(2), 383-401.

Vignolles, M., Jeantet, R., Lopez, C., \& Schuck, P. (2007). Free fat, surface fat and dairy powders : interactions between process and product . A review. Le Lait, 87(3), 187-236.

Wang, T., \& Johnson, L. A. (2001). Refining high-free fatty acid wheat germ oil. Journal of the American Oil Chemists' Society, 78(1), 71-76.

Wrigley, C. W., \& Batey, I. L. (2010). Cereal Grains: Assessing and Managing Quality. UK, Woodhead Publishing Limited.

Wsowicz, E., Gramza, A., Hêœ, M., Jeleñ, H. H., Korczak, J., Malecka, M., Szkudlarz, S. M., Rudziñska, M., Samotyja, U., \& Wojtasiak, R. Z. (2004). Oxidation of lipids in food. Polish Journal of Food and Nutrition Sciences, 13(48 61), 87-100.

Yin, W., \& Yates, M. Z. (2008). Effect of Interfacial Free Energy on the Formation of Polymer Microcapsules by Emulsification / Freeze-Drying, Langmuir, (21), 701-708.

Yu, L. (2008). Wheat Antioxidants. New Jersey, John Wiley \& Sons. 
APPENDIX A

CALIBRATION CURVE

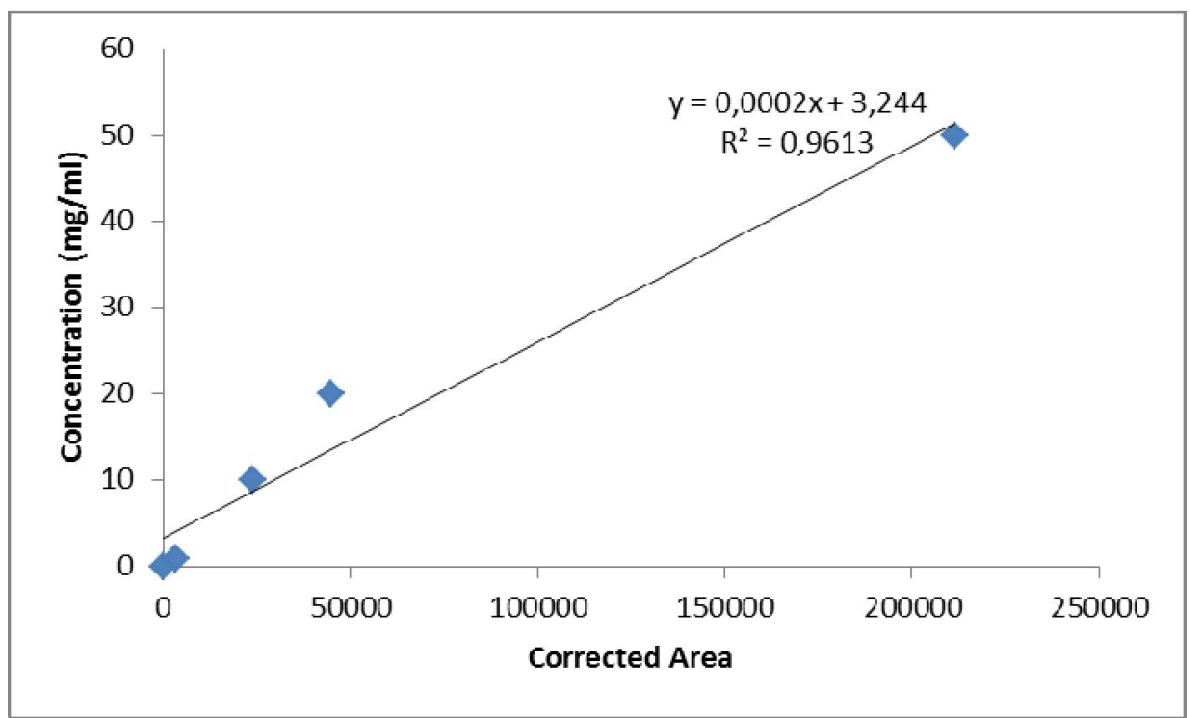




\section{APPENDIX B}

\section{STATISTICAL ANALYSES}

Table B.1 One way ANOVA and Duncan's Multiple Range Test for encapsulation efficiencies of core to coatings MD(4-7):NaCa-1:3, WPC:CS-10:1, MD(4-7):CS-10:1, WPC:CS-1:1, MD(4-7):WPC-1:4, MD(4-7):WPC-1:3, MD(47):GA-1:3

$\mathrm{X} 1$ core to coating

Class Level Information

Class Levels Values

$\mathrm{X} 1 \quad 7 \quad 1234567$

Number of Observations Read 14

Number of Observations Used 14

Dependent Variable: Y

$\begin{array}{lccccc}\text { Source } & \text { DF } & \text { Squares } & \text { Mean Square } & \text { F Value } & \operatorname{Pr}>\text { F } \\ \text { Model } & 6 & 606.2556429 & 101.0426071 & 3.00 & 0.0886 \\ \text { Error } & 7 & 236.0824500 & 33.7260643 & & \\ \text { Corrected Total } & 13 & 842.3380929 & & & \end{array}$




$\underline{\text { R-Square }}$ Coeff Var Root MSE $\quad$ Y Mean

$\begin{array}{llll}0.719730 & 14.04478 \quad 5.807415 & 41.34929\end{array}$

$\begin{array}{lllllll}\text { Source } & \text { DF } & \text { Type I SS } & \text { Mean Square } & \text { F Value } & \text { Pr }>\text { F } \\ \text { X1 } & 6 & 606.2556429 & 101.0426071 & 3.00 & 0.0886\end{array}$

Source DF Type III SS Mean Square F Value $\operatorname{Pr}>$ F

$\begin{array}{llllll}\mathrm{X} 1 & 6 & 606.2556429 & 101.0426071 & 3.00 & 0.0886\end{array}$

\section{Duncan's Multiple Range Test for $Y$}

NOTE: This test controls the Type I comparison wise error rate, not the experiment wise error rate.

Alpha $\quad 0.05$

Error Degrees of Freedom 7

Error Mean Square $\quad 33.72606$

$\begin{array}{llllllll}\text { Number of Means } & 2 & 3 & 4 & 5 & 6 & 7\end{array}$

$\begin{array}{lllllll}\text { Critical Range } \quad 13.73 & 14.28 & 14.57 & 14.74 & 14.83 & 14.87\end{array}$

Means with the same letter are not significantly different. 


\begin{tabular}{|c|c|c|c|c|c|c|}
\hline & an Groupi & & & Mean & $\mathrm{N}$ & $\mathrm{X}$ \\
\hline A & & & & 56.685 & 2 & 7 \\
\hline B & & & & 40.860 & 2 & 5 \\
\hline B & & & & 40.330 & 2 & 4 \\
\hline B & & & & 39.790 & 2 & 6 \\
\hline B & & & & 39.420 & 2 & 2 \\
\hline B & 38.060 & 2 & 1 & & & \\
\hline & 34.300 & & 3 & & & \\
\hline
\end{tabular}

Table B.2 One way ANOVA and Duncan's Multiple Range Test for encapsulation efficiencies of microcapsules prepared with MD:NaCa ratio of 1:3 and homogenized with different techniques (ultrasonication (US), silent crusher (SC) and microfluidization (MF))

\section{Duncan's Multiple Range Test for $Y$}

NOTE: This test controls the Type I comparison wise error rate, not the experiment wise error rate.

Alpha $\quad 0.05$

Error Degrees of Freedom 3

Error Mean Square $\quad 5.047783$ 


$\begin{array}{lrr}\text { Number of Means } & 2 & 3 \\ \text { Critical Range } & 7.150 & 7.174\end{array}$

Means with the same letter are not significantly different.

Duncan Grouping $\quad$ Mean $\quad \mathrm{N} \quad \mathrm{X} 1$

$\begin{array}{llll}\text { A } & 75.595 & 2 & 3 \\ \text { A } & 73.535 & 2 & 2 \\ \text { B } & 56.685 & 2 & 1\end{array}$

Table B.3 One way ANOVA and Duncan's Multiple Range Test for encapsulation efficiencies of microcapsules prepared with MD:NaCa ratio of 1:3 and homogenized under different microfluidization treatment passes

$\mathrm{X} 1$ number of passes

Class Level Information

Class Levels Values

$\begin{array}{llll}\mathrm{X} 1 & 3 & 123\end{array}$

Number of Observations Read 6 


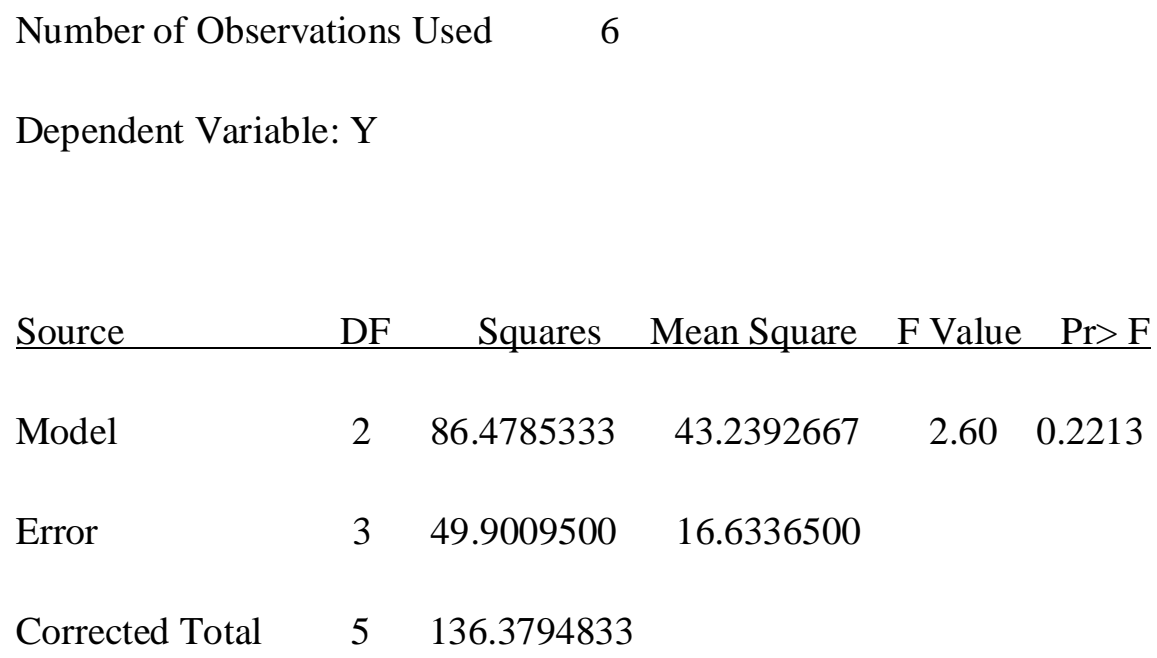

$\underline{\text { R-Square }}$ Coeff Var Root MSE $\quad$ Y Mean

$\begin{array}{llll}0.634102 & 5.189622 & 4.078437 & 78.58833\end{array}$

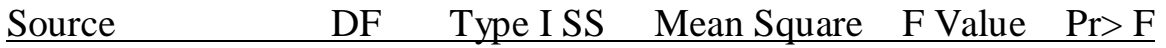

$\begin{array}{llllll}X 1 & 2 & 86.47853333 & 43.23926667 & 2.60 & 0.2213\end{array}$

Source DF Type III SS Mean Square F Value $\operatorname{Pr}>$ F

$\mathrm{X} 1$

$\begin{array}{lllll}2 & 86.47853333 & 43.23926667 & 2.60 & 0.2213\end{array}$

\section{Duncan's Multiple Range Test for Y}

NOTE: This test controls the Type I comparison wise error rate, not the experiment wise error rate.
Alpha
0.05 


$\begin{array}{lrr}\text { Error Degrees of Freedom } & 3 \\ \text { Error Mean Square } & 16.63365 \\ & & \\ & & 3 \\ \text { Number of Means } & 2 & 3 \\ \text { Critical Range } & 12.98 & 13.02\end{array}$

Means with the same letter are not significantly different.

$\begin{array}{llll}\text { Duncan Grouping } & \text { Mean } & \text { N } & \text { X1 } \\ \text { A } & 83.945 & 2 & 3 \\ \text { A } & 76.225 & 2 & 2 \\ \text { A } & 75.595 & 2 & 1\end{array}$

Table B.4 One way ANOVA and Duncan's Multiple Range Test for D32 values of emulsions homogenized by US, SC and MF prepared with MD:NaCa ratio of $1: 3$

X1 homogenization techniques

Class Level Information 


$\underline{\text { Class Levels Values }}$

$\mathrm{X} 1 \quad 3 \quad 123$

Number of Observations Read 9

Number of Observations Used 9

Dependent Variable: Y

$\begin{array}{lccccc}\text { Source } & \text { DF } & \text { Squares } & \text { Mean Square } & \text { F Value } & \text { Pr }>\text { F } \\ \text { Model } & 2 & 1.82876089 & 0.91438044 & 842.14 & <.0001 \\ \text { Error } & 6 & 0.00651467 & 0.00108578 & & \\ & & & & & \\ \text { Corrected Total } & 8 & 1.83527556 & & & \end{array}$

$\underline{\text { R-Square }}$ Coeff Var Root MSE $\quad$ Y Mean

$\begin{array}{llll}0.996450 & 2.594124 & 0.032951 & 1.270222\end{array}$

Source DF Type ISS Mean Square F Value $\operatorname{Pr}>$ F

$\begin{array}{llllll}\mathrm{X} 1 & 2 & 1.82876089 & 0.91438044 & 842.14 & <.0001\end{array}$

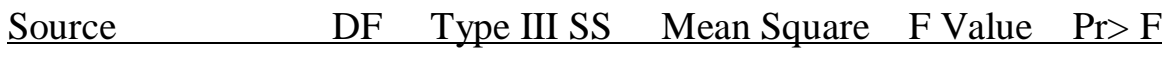

$\begin{array}{llllll}\mathrm{X} 1 & 2 & 1.82876089 & 0.91438044 & 842.14 & <.0001\end{array}$

Duncan's Multiple Range Test for Y 
NOTE: This test controls the Type I comparison wise error rate, not the experiment wise error rate.

Alpha $\quad 0.05$

Error Degrees of Freedom 6

Error Mean Square $\quad 0.001086$

Number of Means 23

Critical Range $\quad .06583 \quad .06823$

Means with the same letter are not significantly different.

Duncan Grouping $\quad$ Mean N X1

$\begin{array}{llll}\text { A } & 1.68667 & 3 & 1 \\ \text { B } & 1.48000 & 3 & 2 \\ \text { C } & 0.64400 & 3 & 3\end{array}$

Table B. 5 One way ANOVA and Duncan's Multiple Range Test for span values of emulsions homogenized by US, SC and MF prepared with MD:NaCa ratio of $1: 3$

$\mathrm{X} 1$ homogenization techniques 


Class Level Information
\begin{tabular}{lll} 
Class & Levels & Values \\
\hline X1 & 3 & 123
\end{tabular}

Number of Observations Read
Number of Observations Used

$\begin{array}{lccccc}\text { Source } & \text { DF } & \text { Squares } & \text { Mean Square } & \text { F Value } & \text { Pr> F } \\ \text { Model } & 2 & 111.2065816 & 55.6032908 & 0.95 & 0.4396 \\ \text { Error } & 6 & 352.8219487 & 58.8036581 & & \\ & & & & & \\ \text { Corrected Total } & 8 & 464.0285302 & & & \end{array}$

\begin{tabular}{llll} 
R-Square & Coeff Var & Root MSE & Y Mean \\
\hline 0.239655 & 154.0277 & 7.668354 & 4.978556
\end{tabular}

$\begin{array}{lrrrrr}\text { Source } & \text { DF } & \text { Type I SS } & \text { Mean Square } & \text { F Value } & \text { Pr> F } \\ \text { X1 } & 2 & 111.2065816 & 55.6032908 & 0.95 & 0.4396\end{array}$

Source DF Type III SS Mean Square F Value Pr> F 


\section{Duncan's Multiple Range Test for $Y$}

NOTE: This test controls the Type I comparison wise error rate, not the experiment wise error rate.
Alpha
0.05
Error Degrees of Freedom 6
Error Mean Square $\quad 58.80366$

Number of Means $\quad 2 \quad 3$

Critical Range $\quad 15.32 \quad 15.88$

Means with the same letter are not significantly different.

$\begin{array}{llll}\text { Duncan Grouping } & \text { Mean } & \text { N } & \text { X1 } \\ \text { A } & 9.629 & 3 & 2 \\ \text { A } & 4.175 & 3 & 1 \\ \text { A } & 1.132 & 3 & 3\end{array}$


Table B. 6 One way ANOVA and Duncan's Multiple Range Test for D32 values of emulsions prepared with $\mathrm{MD}: \mathrm{NaCa}$ ratio of $1: 3$ and homogenized with different microfluidization treatment passes

$\mathrm{X} 1$ number of passes

Class Level Information

Class Levels Values

$\begin{array}{lll}\mathrm{X} 1 & 3 & 123\end{array}$

Number of Observations Read 9

Number of Observations Used 9

Dependent Variable: Y

$\begin{array}{lccccc}\text { Source } & \text { DF } & \text { Squares } & \text { Mean Square } & \text { F Value } & \operatorname{Pr}>\text { F } \\ \text { Model } & 2 & 0.24298400 & 0.12149200 & 503.42 & <.0001 \\ \text { Error } & 6 & 0.00144800 & 0.00024133 & & \\ & & & & & \\ \text { Corrected Total } & 8 & 0.24443200 & & & \end{array}$

R-Square Coeff Var Root MSE $\quad$ Y Mean

$\begin{array}{llll}0.994076 & 3.764517 & 0.015535 & 0.412667\end{array}$ 


$\begin{array}{lccccc}\text { Source } & \text { DF } & \text { Type I SS } & \text { Mean Square } & \text { F Value } & \text { Pr }>\text { F } \\ \text { X1 } & 2 & 0.24298400 & 0.12149200 & 503.42 & <.0001 \\ & & & & & \\ & & & & & \\ \text { Source } & \text { DF } & \text { Type III SS } & \text { Mean Square } & \text { F Value } & \text { Pr }>\text { F } \\ \text { X1 } & 2 & 0.24298400 & 0.12149200 & 503.42 & <.0001\end{array}$

\section{Duncan's Multiple Range Test for $Y$}

NOTE: This test controls the Type I comparison wise error rate, not the experiment wise error rate.

Alpha
Error Degrees of Freedom
Error Mean Square 0.05

Number of Means $\quad 2 \quad 3$

Critical Range $\quad .03104 \quad .03217$

Means with the same letter are not significantly different. 


$\begin{array}{llll}\text { Duncan Grouping } & \text { Mean } & \text { N } & \text { X1 } \\ \text { A } & 0.64400 & 3 & 1 \\ \text { B } & 0.31600 & 3 & 2 \\ \text { C } & 0.27800 & 3 & 3\end{array}$

Table B. 7 One way ANOVA and Duncan's Multiple Range Test for span values of emulsions prepared with $\mathrm{MD}: \mathrm{NaCa}$ ratio of $1: 3$ and homogenized with different microfluidization treatment passes

$\mathrm{X} 1$ number of passes

Class Level Information

Class Levels Values

$\mathrm{X} 1 \quad 3 \quad 123$

Number of Observations Read 9

Number of Observations Used 9

Dependent Variable: Y

$\begin{array}{lrrrrr}\text { Source } & \text { DF } & \text { Squares } & \text { Mean Square } & \text { F Value } & \text { Pr }>\text { F } \\ \text { Model } & 2 & 22.87163822 & 11.43581911 & 58.38 & 0.0001 \\ \text { Error } & 6 & 1.17534867 & 0.19589144 & & \\ & & & & & \\ \text { Corrected Total } & 8 & 24.04698689 & & & \end{array}$




$\underline{\text { R-Square }}$ Coeff Var Root MSE $\quad$ Y Mean

$\begin{array}{llll}0.951123 & 23.04122 & 0.442596 & 1.920889\end{array}$

$\begin{array}{lrrrrr}\text { Source } & \text { DF } & \text { Type I SS } & \text { Mean Square } & \text { F Value } & \text { Pr }>\text { F } \\ \text { X1 } & 2 & 22.87163822 & 11.43581911 & 58.38 & 0.0001\end{array}$

Source DF Type III SS Mean Square F Value $\operatorname{Pr}>F$

$\begin{array}{llllll}\mathrm{X} 1 & 2 & 22.87163822 & 11.43581911 & 58.38 & 0.0001\end{array}$

\section{Duncan's Multiple Range Test for Y}

NOTE: This test controls the Type I comparison wise error rate, not the experiment wise error rate.

Alpha $\quad 0.05$

Error Degrees of Freedom 6

Error Mean Square $\quad 0.195891$

Number of Means $\quad 2 \quad 3$

Critical Range $\quad .8843 \quad .9165$

Means with the same letter are not significantly different. 


\begin{tabular}{llll}
\multicolumn{3}{c}{ Duncan Grouping } \\
A & 4.1747 & 3 & 1 \\
B & 0.8420 & 3 & 2 \\
B & 0.7460 & 3 & 3
\end{tabular}

